\title{
Multigram Mechanochemical synthesis of a Salophen Complex: A Comparative Analysis
}

Varun Kumar Singh, ${ }^{\mathrm{a}, \dagger}$ Alex Chamberlain-Clay, ${ }^{\mathrm{a}, \dagger}$ How Chee Ong, ${ }^{\mathrm{a}}$ Felix León, ${ }^{\mathrm{a}}$ Gavin Hum, ${ }^{\mathrm{a}}$ Mian Yang Par, ${ }^{a}$ Patrick Daley-Dee, ${ }^{a}$ Felipe García ${ }^{a},{ }^{*}$

a School of Physical and Mathematical Sciences, Division of Chemistry and Biological Chemistry, Nanyang Technological University, 21 Nanyang Link, 637371, Singapore

KEYWORDS: Mechanosynthesis, multi-gram, group 13, salen, salophen, E-factor, sustainable

Table of Contents

Number of figures................................................................... 25

Number of tables.................................................................. 1

Number of pages.................................................................. $\quad 37$

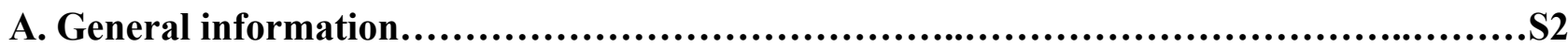

A-1. Compound preparations

A-1-1. Chemicals

A-1-2. Synthetic details

A-1-3. Mechanosynthesis apparatus

A-2. Analytical measurements

A-2-1. Characterization of synthesized compounds

B. Synthesis of Salen-Salophen ligands and complexes.....................................S3

C. Structural analysis of synthesized ligands and complexes...............................8

C-1. NMR spectra

C-2. Mass Spectroscopic analyses

C-3. IR spectra

D. Green chemistry metrics (GCM) calculations for Br-Salophen-Al (CI).

D-1. E-factor

D-2. Process mass intensity (PMI) calculations

D-3. Generalized Reaction mass efficiency (RME)

D-4. Energy Usage Calculation

D-5. Cost Calculation 


\section{A. General Information}

\section{A-1. Compound preparations}

\section{A-1-1. Chemicals}

All the ligands and metal complexes were synthesized according to the procedures shown Figure $3 \mathrm{a}$. Unless otherwise specified, all chemicals and solvents were purchased commercially and used without further purification.

\section{A-1-2. Synthetic details}

The progress of the reaction was checked by ${ }^{1} \mathrm{H}$ NMR analysis by taking a small aliquot from the reaction mixture and running acquisitions soon after without aging the samples. The compounds were purified by filtration where needed and dried in oven.

\section{A-1-3. Mechanosynthesis apparatus}

The ball mills used for up to $5 \mathrm{~g}, 30 \mathrm{~g}$ and $120 \mathrm{~g}$ scale reactions were Retsch MM400, Retsch PM100 and Grinder BM4 respectively (Figure S1). The milling jars and balls were made of stainless steel, and the balls used were 5 or $8 \mathrm{~mm}$ in diameter. An additional Teflon ring was used to ensure an airtight seal for MM400 jars.

a)

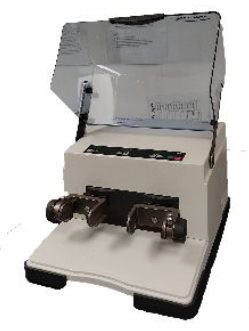

b)

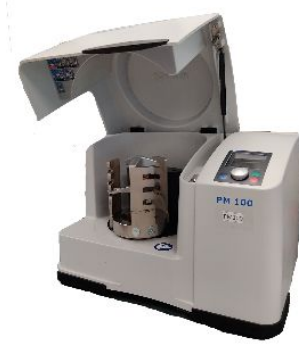

c)

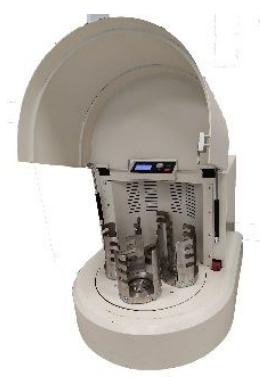

Figure S1. Ball mills used in this work (a) Retsch MM400 (b) Retsch PM100 (c) Grinder BM4

\section{A-2. Analytical measurements}

\section{A-2-1. Characterization of synthesized compounds}

All the synthesized compounds were characterized by ${ }^{1} \mathrm{H}-\mathrm{NMR}$, and mass spectroscopy. ${ }^{1} \mathrm{H}-\mathrm{NMR}$ spectra were recorded on a Bruker BBFO400 (400 MHz) as a DMSO- $\mathrm{d}_{6}$ solution. Chemical shift values were recorded as parts per million relative to tetramethylsilane as an internal standard, and coupling constants in Hertz. High resolution mass spectra were recorded on a Waters Q-TOF Premier system using electrospray ionization in positive ion detection (ESI+) mode. 


\section{B. Synthesis of salen/salophen ligands and complexes}

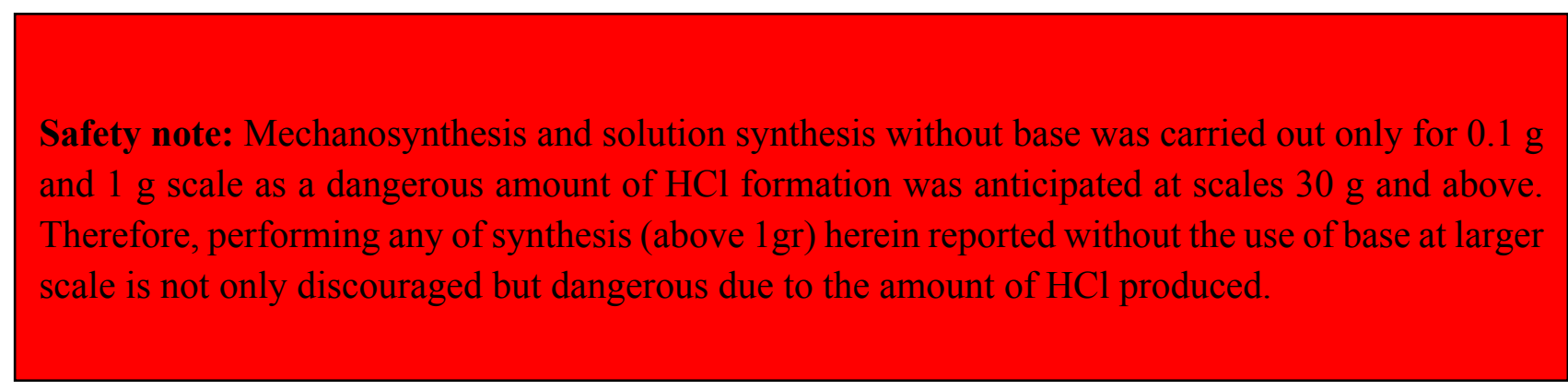

Br-Salophen: An oven-dried stainless-steel grinder jar was charged with 5-bromo-2hydroxybenzaldehyde $(1.01 \mathrm{~g}, 5 \mathrm{mmol})$ and 1, 2-phenylenediamine $(0.27 \mathrm{~g}, 2.5 \mathrm{mmol})$. The jar was grinded for 2 hour to give a free-flowing orange powder. The product was then dried for $36 \mathrm{~h}$ in an oven to drive off the water by product to give qualitative conversion (Yield $=98 \%) .{ }^{1} \mathrm{H}$ NMR (400 MHz, DMSO- $\left.d_{6}\right) \delta 12.92(\mathrm{~s}, 2 \mathrm{H}), 8.92(\mathrm{~s}, 2 \mathrm{H}), 7.90(\mathrm{~d}, J=2.5 \mathrm{~Hz}, 2 \mathrm{H}), 7.56-7.53(\mathrm{~d}, J=2.4 \mathrm{~Hz}, 2 \mathrm{H})$, $7.48-7.41(\mathrm{~m}, 4 \mathrm{H}), 6.96-6.93(\mathrm{~d}, J=8.9 \mathrm{~Hz}, 2 \mathrm{H}) .{ }^{13} \mathrm{C}$ NMR $\left(100.6 \mathrm{MHz}, \mathrm{DMSO}-d_{6}\right) \delta 162.7,159.3$, $141.6,136.1,134.2,128.6,121.9,121.1,119.6,110.4$. TOF-MS-ES+ for $[\mathrm{M}+\mathrm{H}]^{+}:$Calcd. $\mathrm{m} / \mathrm{z}$ 474.9480; Found 474.9481.

Br-Salen: An oven-dried stainless-steel grinder jar was charged with 5-bromo-2hydroxybenzaldehyde $(1.01 \mathrm{~g}, 5 \mathrm{mmol})$ and ethylenediamine $(0.165 \mathrm{ml}, 2.5 \mathrm{mmol})$. The jar was grinded for 2 hours to give a free-flowing yellow powder. The product was then dried for $36 \mathrm{~h}$ in an oven to drive off the water byproduct to give qualitative conversion (Yield $=92 \%)$. ${ }^{1} \mathrm{H}$ NMR $(400$ Mhz, DMSO-d $\left.{ }_{6}\right) \delta 13.45(\mathrm{~s}, 2 \mathrm{H}), 8.59(\mathrm{~s}, 2 \mathrm{H}), 7.46(\mathrm{~d}, J=12.1 \mathrm{~Hz}, 4 \mathrm{H}), 6.85(\mathrm{~d}, J=8.6 \mathrm{~Hz}, 2 \mathrm{H}), 3.94$ $(\mathrm{s}, 4 \mathrm{H}) .{ }^{13} \mathrm{C}$ NMR $\left(100.6 \mathrm{MHz}, \mathrm{DMSO}-\mathrm{d}_{6}\right) \delta 165.5,160.2,135.3,133.7,120.1,119.2,110.3,59.8$. TOF-MS-ES+ for $[\mathrm{M}+\mathrm{H}]^{+}$: Calcd. m/z 426.9480; Found 426.9481

Br-Salophen-Al (1): An oven-dried stainless-steel grinder jar was charged with Br-Salophen 3 (1 g, $2.1 \mathrm{mmol})$ and aluminium trichloride $(0.33 \mathrm{~g}, 2.53 \mathrm{mmol})$. The jar was then grinded for 4 hours to give a yellow-orange powder with complete conversion to product. The product was then washed with water to remove $\mathrm{HCl}$ by-product and then dried in an oven (Yield =97\%). ${ }^{1} \mathrm{H} \mathrm{NMR}(400 \mathrm{Mhz}$, DMSO$\left.d_{6}\right) \delta 9.31(\mathrm{~s}, 2 \mathrm{H}), 8.09(\mathrm{~m}, 2 \mathrm{H}), 7.88(\mathrm{~d}, J=2.9 \mathrm{~Hz}, 2 \mathrm{H}), 7.59-7.54(\mathrm{~m}, 4 \mathrm{H}), 6.90(\mathrm{~d}, J=8.9 \mathrm{~Hz}$, 2H). ${ }^{13} \mathrm{C}$ NMR (100.6 MHz, DMSO- $\left.d_{6}\right) \delta 164.8,161.3,139.4,137.7,137.6,129.8,124.3,121.6,117.8$, 107.3 TOF-MS-ES+ for [M-Cl] $]^{+}$: Calcd. m/z 498.9061; Found 498.9060.

Br-Salophen-In (2): An oven-dried stainless-steel grinder jar was charged with Br-Salophen 3 (0.1 g, $0.21 \mathrm{mmol})$, indium trichloride $(56 \mathrm{mg}, 0.25 \mathrm{mmol})$ and anhydrous magnesium sulfate $(200 \mathrm{mg})$. The jar was grinded for 6 hours to give orange powder. The product was then washed with water to remove $\mathrm{HCl}$ by-product and then dried in an oven (Yield = 70\%). ${ }^{1} \mathrm{H}$ NMR (400 Mhz, DMSO- $\left.d_{6}\right) \delta 9.12(\mathrm{~s}$, 2H), $8.01(\mathrm{~s}, 2 \mathrm{H}), 7.81(\mathrm{~s}, 2 \mathrm{H}), 7.2(\mathrm{~m}, 4 \mathrm{H}), 6.79(\mathrm{~d}, J=8.9 \mathrm{~Hz}, 2 \mathrm{H}) .{ }^{13} \mathrm{C}$ NMR (100.6 MHz, DMSO$\left.d_{6}\right) \delta 169.6,165.2,139.3,138.5,137.1,129.4,121.4,118.5,106.2$. TOF-MS-ES+ for $[\mathrm{M}-\mathrm{Cl}]^{+}$: Calcd. $\mathrm{m} / \mathrm{z}$ 586.6284; Found 586.8283.

Br-Salen-Al (3): An oven-dried stainless-steel grinder jar was charged with Br-Salen 1 (0.1 g, 0.23 $\mathrm{mmol}$ ) and aluminium trichloride $(38 \mathrm{mg}, 0.28 \mathrm{mmol})$ and anhydrous magnesium sulfate $(200 \mathrm{mg})$. 
The jar was grinded for 6 hours to give a brown powder, with complete conversion and the crude was washed in water before being filtered and dried, giving the product (Yield $=77 \%) .{ }^{1} \mathrm{H} \mathrm{NMR}(400 \mathrm{Mhz}$, DMSO- $\left.d_{6}\right) \delta 8.59(\mathrm{~s}, 2 \mathrm{H}), 767(\mathrm{~s}, 2 \mathrm{H}), 7.47(\mathrm{~d}, J=8.8 \mathrm{~Hz}, 2 \mathrm{H}), 6.85(\mathrm{~s}, J=9.2 \mathrm{~Hz}, 2 \mathrm{H}), 3.94(\mathrm{~s}, 4 \mathrm{H})$. ${ }^{13} \mathrm{C}$ NMR $\left(100.6 \mathrm{MHz}\right.$, DMSO- $\left.d_{6}\right) \delta 166.1,160.4,135.3,133.9,120.7,119.5,109.6,58.9$. TOF-MS$\mathrm{ES}+$ for $[\mathrm{M}-\mathrm{Cl}]^{+}:$Calcd. m/z 450.9060; Found 450.9058.

Br-Salen-In (4): An oven-dried stainless-steel grinder jar was charged with Br-Salen 1 (0.1 g, 0.23 mmol) and indium trichloride $(61 \mathrm{mg}, 0.27 \mathrm{mmol})$ and anhydrous magnesium sulfate $(200 \mathrm{mg})$. The jar was grinded for 6 hours to give a bright orange powder. The crude was then washed with water before being filtered and dried, giving the product (Yield $=70 \%) .{ }^{1} \mathrm{H}$ NMR $\left(400 \mathrm{Mhz}, \mathrm{DMSO}-d_{6}\right) \delta$ $8.47(\mathrm{~s}, 2 \mathrm{H}), 7.47(\mathrm{~s}, 2 \mathrm{H}), 7.38(\mathrm{~d}, 2 \mathrm{H}), 6.70(\mathrm{~s}, 2 \mathrm{H}), 3.88(\mathrm{~s}, 4 \mathrm{H}) .{ }^{13} \mathrm{C}$ NMR $\left(100.6 \mathrm{MHz}, \mathrm{DMSO}-d_{6}\right)$ $\delta 166.2,160.5,135.4,133.9,120.7,119.6,109.6,58.9$. TOF-MS-ES + for $[\mathrm{M}-\mathrm{Cl}]^{+}:$Calcd. $\mathrm{m} / \mathrm{z}$ 538.8284; Found 538.8282.

\section{Synthetic Procedures for Table 1}

Safety note: Mechanosynthesis and solution synthesis without base was carried out only for $0.1 \mathrm{~g}$ and $1 \mathrm{~g}$ scale as a dangerous amount of $\mathrm{HCl}$ formation was anticipated at scales $30 \mathrm{~g}$ and above, therefore, synthesis without base at larger scale is discouraged.

- Mechanosynthesis

\section{Procedures for Table 1}

Mechanosynthesis and solution synthesis without base was carried out only for $0.1 \mathrm{~g}$ and $1 \mathrm{~g}$ scale as a dangerous amount of $\mathrm{HCl}$ formation was anticipated at scales $30 \mathrm{~g}$ and above, therefore, synthesis without base at larger scale was discouraged.

\section{(Mechanosynthesis)}

Mechano-synthesis of $0.1 \mathrm{~g}$ Br-salophen-Al (Cl): An oven dried stainless steel milling jar was charged with 5-bromo-2-hydroxybenzaldehyde $(81 \mathrm{mg}, 0.402 \mathrm{mmol})$ and 1,2-Phenylenediamine (20 $\mathrm{mg}, 0.185 \mathrm{mmol}$ ) and grinded for 2 hours with 15 minutes cooling breaks every 30 minutes. ${ }^{1} \mathrm{H}$ NMR showed full conversion with free flowing orange powder which was then dried in an oven for $36 \mathrm{~h}$ to obtain pure salophen ligand in $99 \%$ yield $(88 \mathrm{mg})$.

For the complex synthesis, an oven dried stainless steel milling jar was charged with Br-salophen ligand (88 mg, $0.186 \mathrm{mmol})$, aluminium chloride $(29 \mathrm{mg}, 0.217 \mathrm{mmol})$ and grinded for 4 hours with 15 minutes breaks every 30 minutes. The conversion was analysed by ${ }^{1} \mathrm{H}$ NMR and the obtained product was dried in an oven to obtain in $88 \%$ yield $(0.087 \mathrm{~g})$.

Overall yield: $87.12 \%$ 
Mechano-synthesis of $\mathbf{1} \mathbf{g ~ B r}$-salophen-Al (Cl): An oven dried stainless steel milling jar was charged with 5-bromo-2-hydroxybenzaldehyde $(0.805 \mathrm{~g}, 4 \mathrm{mmol})$ and 1,2-Phenylenediamine (0.2 $\mathrm{g}, 1.85$ mmol) and grinded for 2 hours with 15 minutes cooling breaks every 30 minutes. ${ }^{1} \mathrm{H}$ NMR showed full conversion with free flowing orange powder which was then dried in an oven for $36 \mathrm{~h}$ to obtain pure salophen ligand in $98 \%$ yield $(0.88 \mathrm{~g})$.

For the complex synthesis, an oven dried stainless steel milling jar was charged with Br-salophen ligand $(0.88 \mathrm{~g}, 1.82 \mathrm{mmol})$, aluminium chloride $(0.275 \mathrm{~g}, 2.06 \mathrm{mmol})$ and grinded for 4 hours with 15 minutes breaks every 30 minutes. The conversion was analysed by ${ }^{1} \mathrm{H}$ NMR and the obtained product was dried in an oven to obtain in $99 \%$ yield $(0.98 \mathrm{~g})$.

Overall yield: $97.02 \%$

Mechano-synthesis of $30 \mathrm{~g}$ Br-salophen-Al (Cl): An oven dried stainless steel milling jar was charged with 5-bromo-2-hydroxybenzaldehyde (24 g, $0.119 \mathrm{~mol})$ and 1,2-Phenylenediamine (6.5 g, $0.06 \mathrm{~mol}$ ) and grinded for 2 hours with 15 minutes cooling breaks every 30 minutes. ${ }^{1} \mathrm{H}$ NMR showed full conversion with free flowing orange powder which was then dried in an oven for $36 \mathrm{~h}$ to obtain pure salophen ligand in $83 \%$ yield $(23.5 \mathrm{~g})$.

For the complex synthesis, an oven dried stainless steel milling jar was charged with Br-salophen ligand $(23.5 \mathrm{~g}, 0.049 \mathrm{~mol})$, aluminium chloride $(7.6 \mathrm{~g}, 0.057 \mathrm{~mol})$ and triethyl amine $(11.7 \mathrm{~g}, 0.115$ mol), and grinded for 4 hours with 15 minutes breaks every 30 minutes. The conversion was analysed by ${ }^{1} \mathrm{H}$ NMR and the crude product was purified by washing with water $(400 \mathrm{~mL})$ and filtration followed by drying in an oven to obtain in $84 \%$ yield $(22.3 \mathrm{~g})$.

Overall yield: $69.72 \%$

Mechano-synthesis of $60 \mathrm{~g}$ Br-salophen-Al (Cl): An oven dried stainless steel milling jar was charged with 5-bromo-2-hydroxybenzaldehyde (49.5 g, $0.246 \mathrm{~mol}$ ) and 1,2-Phenylenediamine (13.3 g, 0.123 mol) and grinded for 2 hours with 15 minutes cooling breaks every 30 minutes. ${ }^{1} \mathrm{H}$ NMR showed full conversion with free flowing orange powder which was then dried in an oven for $36 \mathrm{~h}$ to obtain pure salophen ligand in $92.25 \%$ yield $(53.8 \mathrm{~g})$.

For the complex synthesis, an oven dried stainless steel milling jar was charged with Br-salophen ligand $(53.8 \mathrm{~g}, 0.114 \mathrm{~mol})$, aluminium chloride $(17.5 \mathrm{~g}, 0.131 \mathrm{~mol})$ and triethyl amine $(25.4 \mathrm{~g}, 0.25$ mol), and grinded for 4 hours with 15 minutes breaks every 30 minutes. The conversion was analysed by ${ }^{1} \mathrm{H}$ NMR and the crude product was purified by washing with water $(800 \mathrm{~mL})$ and filtration followed by drying in an oven to obtain in $89 \%$ yield (53.8 g).

Overall yield: $82.10 \%$

Mechano-synthesis of 120 g Br-salophen-Al (Cl): Two $250 \mathrm{ml}$ stainless steel planetary mill jars were charged with 5-bromo-2-hydroxybenzaldehyde (48.34 g, $0.24 \mathrm{~mol}$ ) and 1,2-Phenylenediamine (13 g, $0.12 \mathrm{~mol}$ ) and grinded for 2 hours with 15 minutes cooling breaks every 30 minutes. ${ }^{1} \mathrm{H}$ NMR showed full conversion with free flowing orange powder which was then dried in an oven for $36 \mathrm{~h}$ to obtain pure salophen ligand in $83 \%$ yield $(47 \mathrm{~g})$ - per jar.

For the complex synthesis, an oven dried stainless steel milling jar was charged with Br-salophen ligand $(47 \mathrm{~g}, 0.0995 \mathrm{~mol})$, aluminium chloride $(13.215 \mathrm{~g}, 0.099 \mathrm{~mol})$ and triethyl amine $(20.5 \mathrm{~g}, 0.20$ 
mol), and grinded for 4 hours with 15 minutes breaks every 30 minutes. The conversion was analysed by ${ }^{1} \mathrm{H}$ NMR and the combined crude product was purified by washing with water $(1600 \mathrm{~mL})$ and filtration followed by drying in an oven to obtain in $85 \%$ yield $(42.50 \mathrm{~g})$ - per jar.

Overall yield: $70.55 \%$

\section{Procedures for Table 1}

\section{(Solution-synthesis)}

Synthesis of 0.1 g Br-salophen-Al (Cl): An oven dried round bottom flask was charged with 5-bromo2-hydroxybenzaldehyde $(0.081 \mathrm{~g}, 0.402 \mathrm{mmol})$ and ethanol $(2 \mathrm{~mL})$. To this solution, 1,2Phenylenediamine $(0.02 \mathrm{~g}, 0.185 \mathrm{mmol})$ was added in one portion and the reaction mixture was heated to reflux for 4 hours under nitrogen atmosphere and the progress of the reaction was checked by TLC and ${ }^{1} \mathrm{H}$ NMR analysis. The obtained yellow suspension was reduced to about $30 \%$ volume in vacuo and the reaction mixture was filtered followed by drying in an oven to obtain pure compound in $88 \%$ yield $(0.077 \mathrm{~g})$. $\mathrm{AlCl}_{3}$

An oven dried round bottom flask was charged with synthesized $\mathrm{Br}$-salophen ligand (0.088 $\mathrm{g}, 0.186$ $\mathrm{mmol})$ and toluene $(1 \mathrm{~mL})$. To this solution was added aluminium chloride $(0.0275 \mathrm{~g}, 0.206 \mathrm{mmol})$ and the reaction mixture was heated to reflux for 12 hours. The obtained yellow suspension was then reduced to about $30 \%$ volume in vacuo and filtered followed by drying in an oven to obtain pure compound in $63.63 \%$ yield $(0.063 \mathrm{~g})$.

Overall yield: $55.99 \%$

Synthesis of $1 \mathrm{~g} \mathrm{Br}$-salophen-Al (Cl): An oven dried round bottom flask was charged with 5-bromo2-hydroxybenzaldehyde (1.022 $\mathrm{g}, 0.005 \mathrm{~mol})$ and ethanol $(15 \mathrm{~mL})$. To this solution, 1,2Phenylenediamine $(0.275 \mathrm{~g}, 0.0025 \mathrm{~mol})$ was added in one portion and the reaction mixture was heated to reflux for 4 hours under nitrogen atmosphere and the progress of the reaction was checked by TLC and ${ }^{1} \mathrm{H}$ NMR analysis. The obtained yellow suspension was reduced to about $30 \%$ volume in vacuo and the reaction mixture was filtered followed by drying in an oven to obtain pure compound in $89 \%$ yield $(1.07 \mathrm{~g})$.

An oven dried round bottom flask was charged with synthesized Br-salophen ligand (0.88 g, 1.86 $\mathrm{mmol})$ and toluene $(8 \mathrm{~mL})$. To this solution was added aluminium chloride $(0.275 \mathrm{~g}, 2.06 \mathrm{mmol})$ and the reaction mixture was heated to reflux for 12 hours. The obtained yellow suspension was then reduced to about $30 \%$ volume in vacuo and filtered followed by drying in an oven to obtain pure compound in $96 \%$ yield $(0.96 \mathrm{~g})$.

Overall yield: $85.44 \%$

Synthesis of $30 \mathrm{~g}$ Br-salophen-Al (Cl): An oven dried round bottom flask was charged with 5-bromo2-hydroxybenzaldehyde $(30 \mathrm{~g}, 0.149 \mathrm{~mol})$ and ethanol $(500 \mathrm{~mL})$. To this solution, 1,2Phenylenediamine $(8.12 \mathrm{~g}, 0.075 \mathrm{mmol})$ was added in one portion and the reaction mixture was heated to reflux for 4 hours under nitrogen atmosphere and the progress of the reaction was checked by TLC 
and ${ }^{1} \mathrm{H}$ NMR analysis. The obtained yellow suspension was reduced to about $30 \%$ volume in vacuo and the reaction mixture was filtered followed by drying in an oven to obtain pure compound in $84.5 \%$ yield (30.1 g).

An oven dried round bottom flask was charged with synthesized Br-salophen ligand (23.5 g, 0.049 $\mathrm{mol})$, triethyl amine $(11.7 \mathrm{~g}, 0.115 \mathrm{~mol})$ and toluene $(250 \mathrm{~mL})$. To this solution was added aluminium chloride $(7.6 \mathrm{~g}, 0.057 \mathrm{~mol})$ and the reaction mixture was heated to reflux for 12 hours. The obtained yellow suspension was then reduced to about $30 \%$ volume in vacuo, filtered and washed with water $(400 \mathrm{~mL})$, followed by drying in an oven to obtain pure compound in $78 \%$ yield $(20.7 \mathrm{~g})$.

Overall yield: $65.91 \%$

Synthesis of $60 \mathrm{~g} \mathrm{Br}$-salophen-Al (Cl): An oven dried round bottom flask was charged with 5-bromo2-hydroxybenzaldehyde $(50 \mathrm{~g}, 0.248 \mathrm{~mol})$ and ethanol $(800 \mathrm{~mL})$. To this solution, 1,2Phenylenediamine (13.5 g, $0.124 \mathrm{~mol}$ ) was added in one portion and the reaction mixture was heated to reflux for 4 hours under nitrogen atmosphere and the progress of the reaction was checked by TLC and ${ }^{1} \mathrm{H}$ NMR analysis. The obtained yellow suspension was reduced to about $30 \%$ volume in vacuo and the reaction mixture was filtered followed by drying in an oven to obtain pure compound in $92 \%$ yield (54.5 g).

An oven dried round bottom flask was charged with synthesized Br-salophen ligand (54.5 g, 0.115 $\mathrm{mol})$, triethyl amine $(24.7 \mathrm{~g}, 0.244 \mathrm{~mol})$ and toluene $(500 \mathrm{~mL})$. To this solution was added aluminium chloride (17.6 g, $0.132 \mathrm{~mol})$ and the reaction mixture was heated to reflux for 12 hours. The obtained yellow suspension was then reduced to about $30 \%$ volume in vacuo and washed with water ( $800 \mathrm{~mL})$, followed by drying in an oven to obtain pure compound in $93 \%$ yield $(57.5 \mathrm{~g})$.

Overall yield: $85.56 \%$

Synthesis of $120 \mathrm{~g}$ Br-salophen-Al (Cl): An oven dried round bottom flask was charged with 5bromo-2-hydroxybenzaldehyde $(96.68 \mathrm{~g}, 0.248 \mathrm{~mol})$ and ethanol $(1600 \mathrm{~mL})$. To this solution, 1,2Phenylenediamine ( $26 \mathrm{~g}, 0.124 \mathrm{~mol}$ ) was added in one portion and the reaction mixture was heated to reflux for 4 hours under nitrogen atmosphere and the progress of the reaction was checked by TLC and ${ }^{1} \mathrm{H}$ NMR analysis. The obtained yellow suspension was reduced to about $30 \%$ volume in vacuo and the reaction mixture was filtered followed by drying in an oven to obtain pure compound in $82.79 \%$ yield $(94.39 \mathrm{~g})$.

An oven dried round bottom flask was charged with synthesized Br-salophen ligand (94.39 g, 0.199 $\mathrm{mol})$, triethyl amine (42 $\mathrm{g}, 0.415 \mathrm{~mol})$ and toluene $(900 \mathrm{~mL})$. To this solution was added aluminium chloride (30.45 g, $0.228 \mathrm{~mol})$ and the reaction mixture was heated to reflux for 12 hours. The obtained yellow suspension was then reduced to about $30 \%$ volume in vacuo and washed with water (1600 mL), followed by drying in an oven to obtain pure compound in $88 \%$ yield $(94 \mathrm{~g})$.

Overall yield: $72.8 \%$ 
C. Structural analysis of synthesized ligands and complexes

C-1. NMR analysis

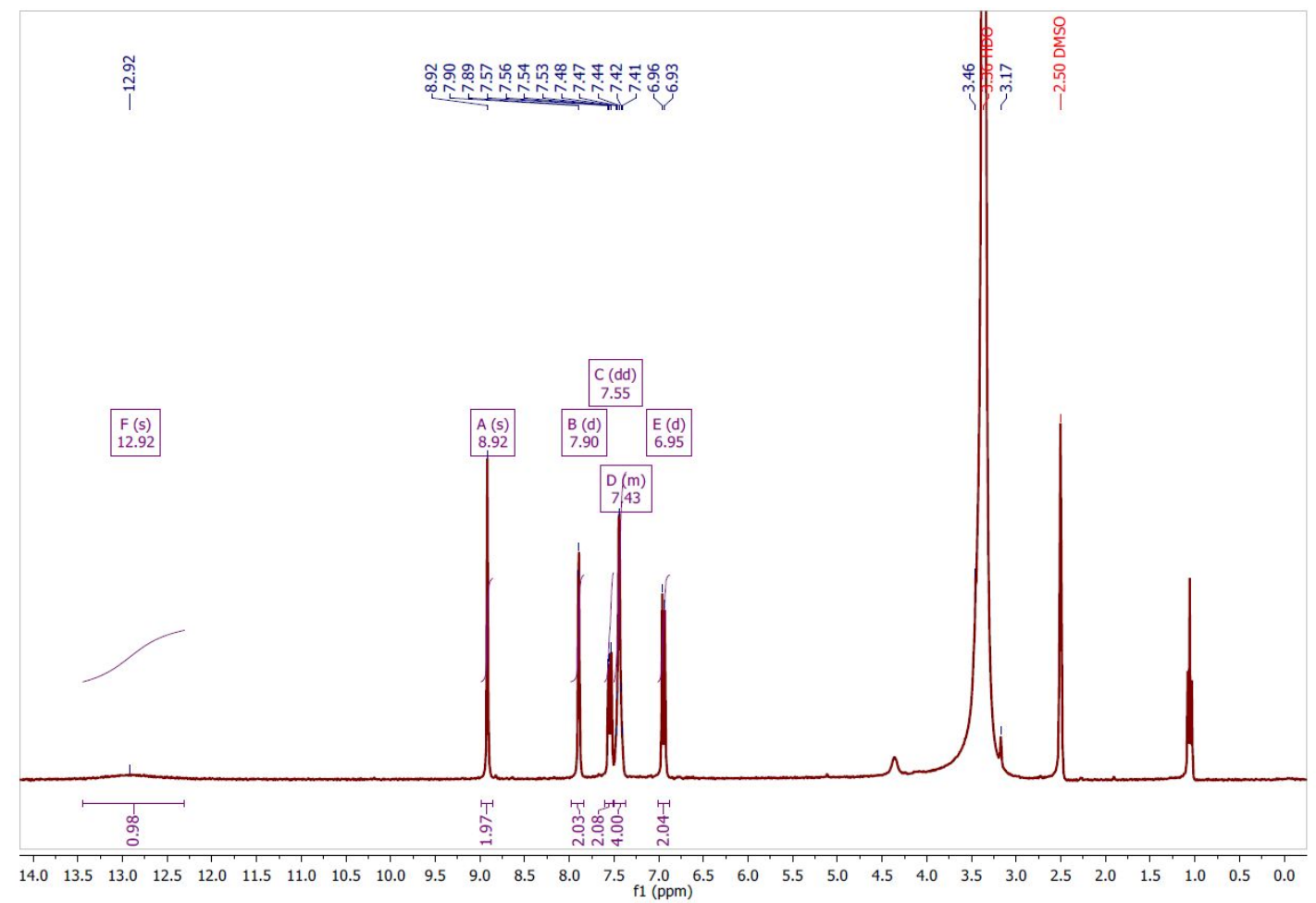

Figure S2. ${ }^{1} \mathrm{H}$ NMR spectrum of Br-Salophen in DMSO-d $\mathrm{d}_{6}$
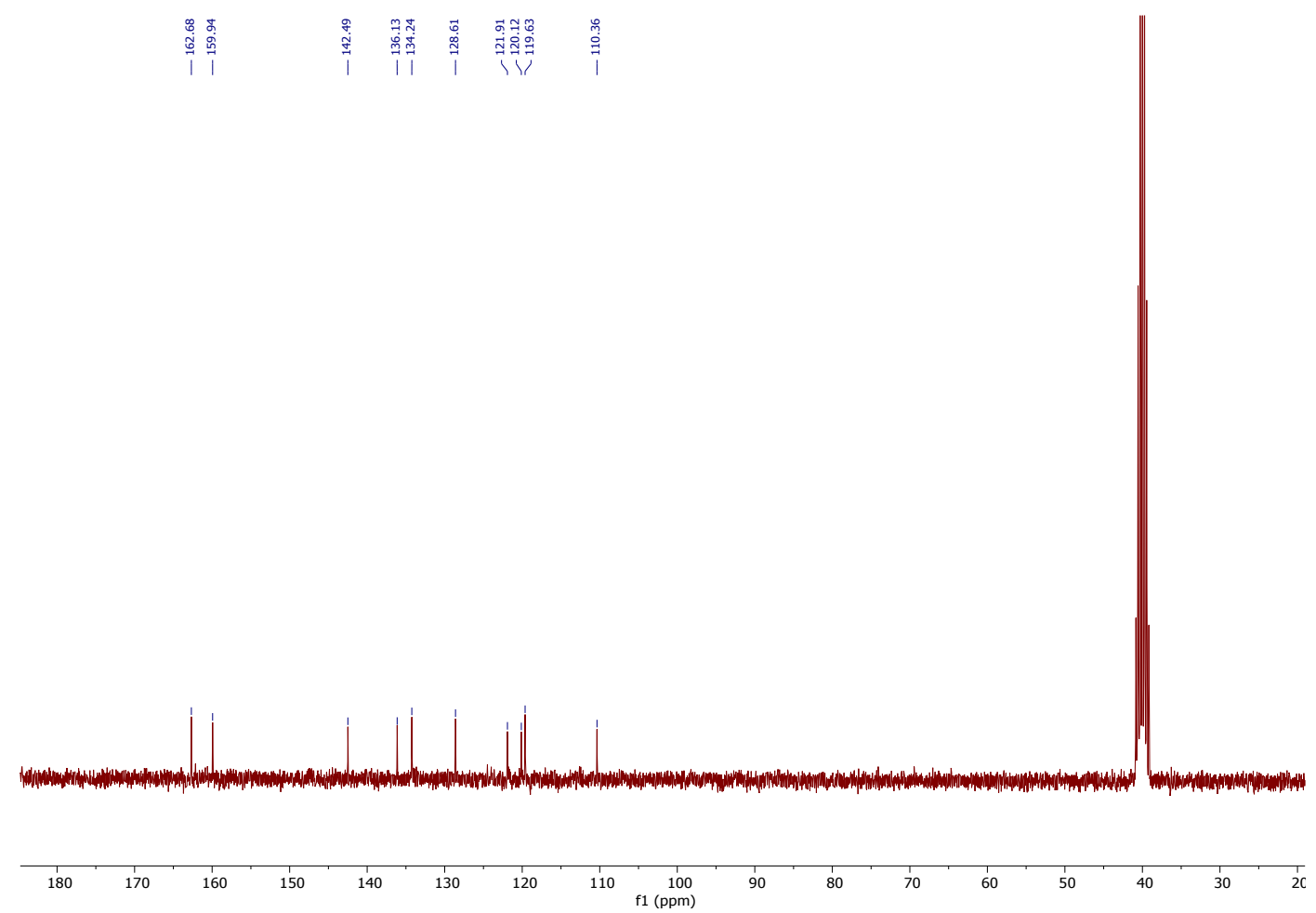

Figure S3. ${ }^{13} \mathrm{C}$ NMR spectrum of Br-Salophen in DMSO-d6 


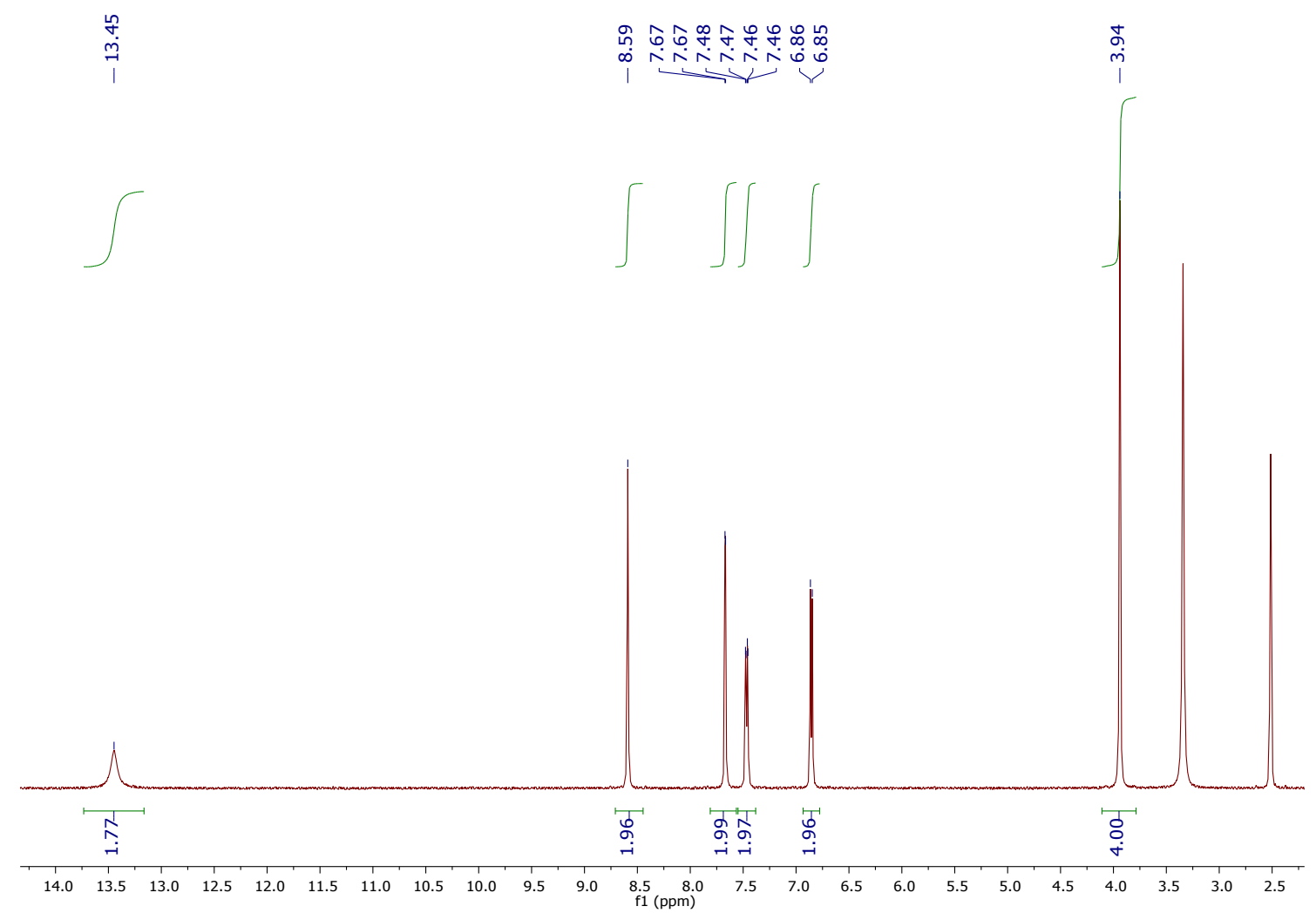

Figure S4. ${ }^{1} \mathrm{H}$ NMR spectrum of Br-Salen in DMSO-d $\mathrm{d}_{6}$

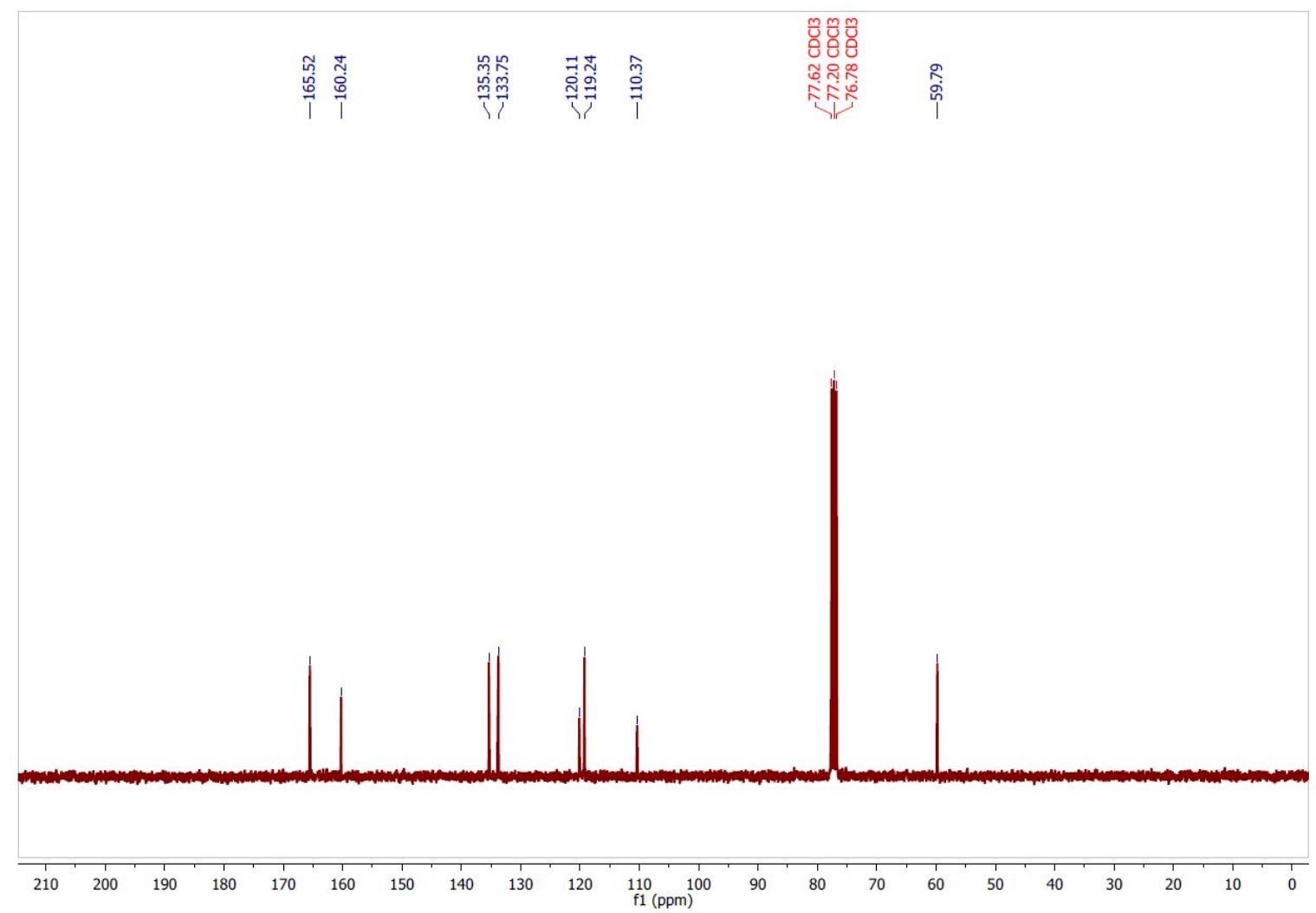

Figure S5. ${ }^{13} \mathrm{C}$ NMR spectrum of Br-Salen in $\mathrm{CDCl}_{3}$ 


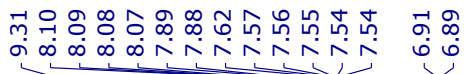
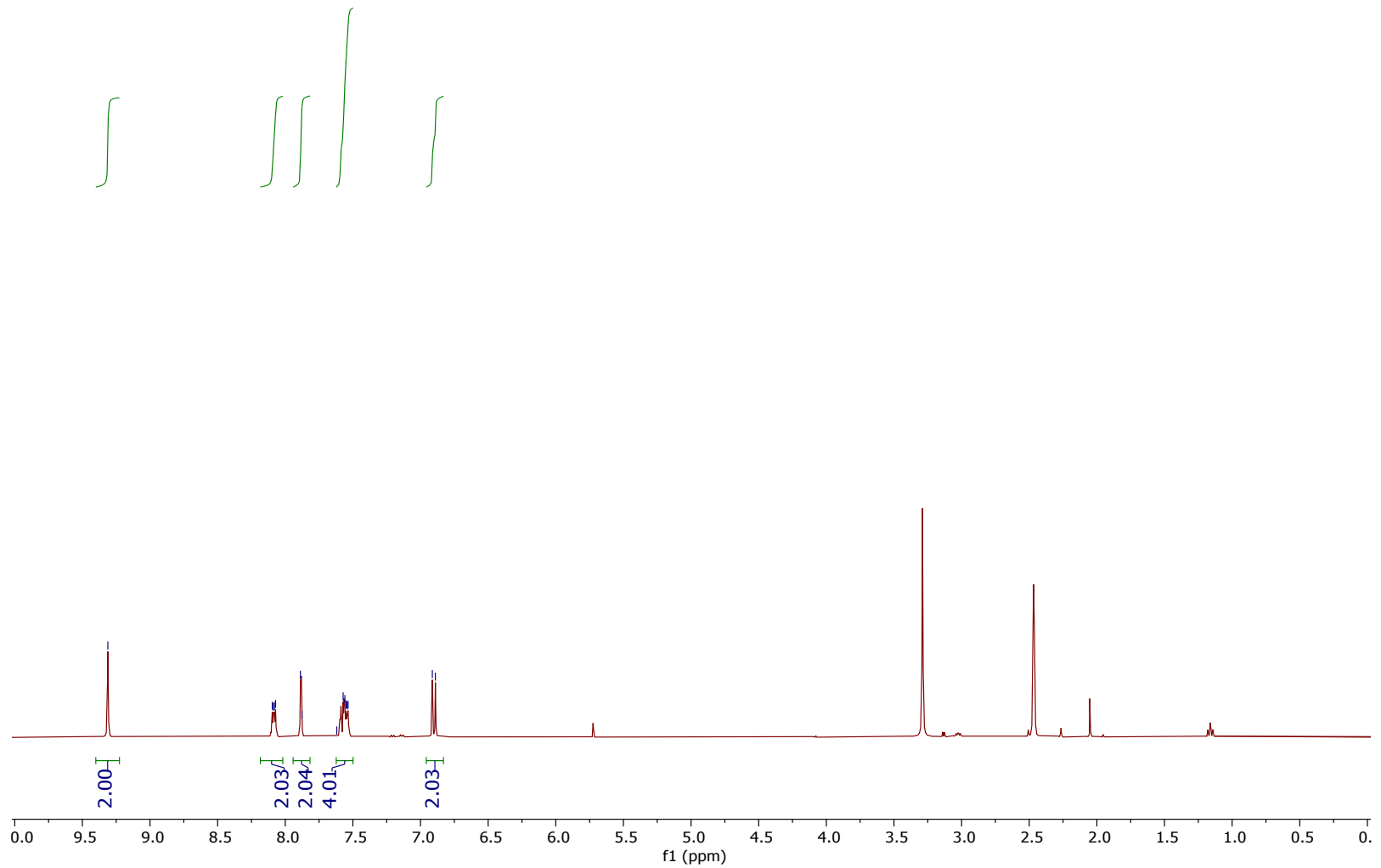

Figure S6. ${ }^{1} \mathrm{H}$ NMR spectrum of 1 in DMSO- $\mathrm{d}_{6}$

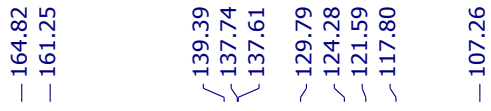
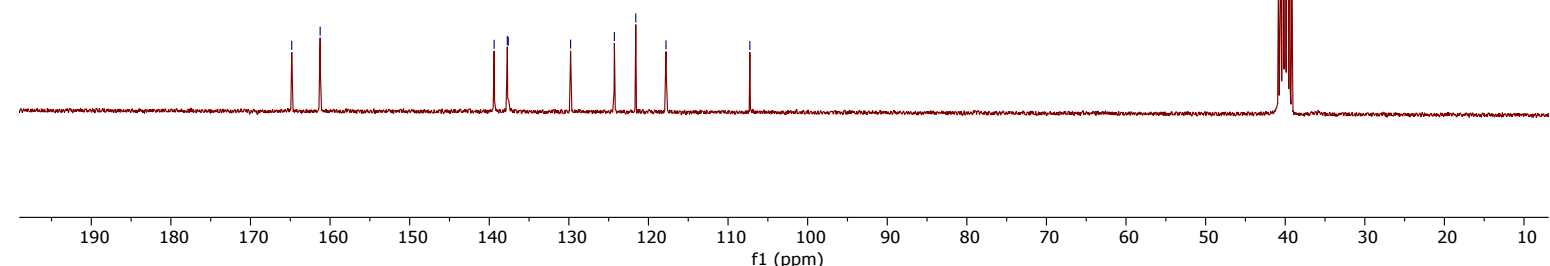

Figure S7. ${ }^{13} \mathrm{C}$ NMR spectrum of 1 in DMSO- $d_{6}$ 


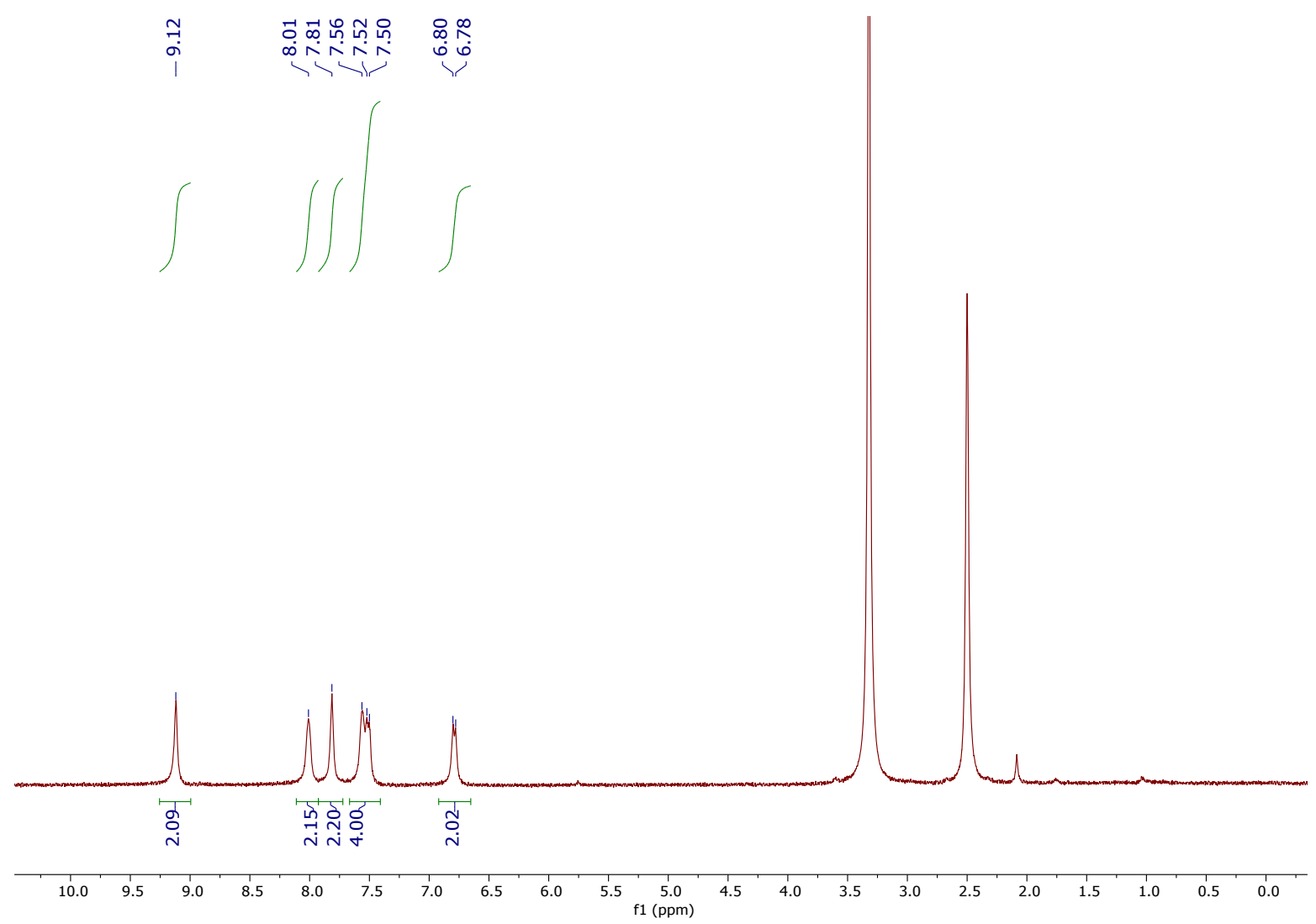

Figure S8. ${ }^{1} \mathrm{H}$ NMR spectrum of 2 in $\mathrm{DMSO}_{-} \mathrm{d}_{6}$

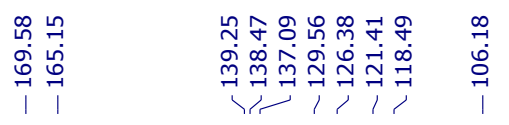

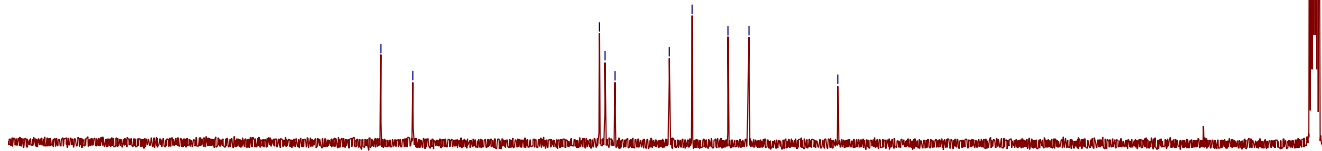

\begin{tabular}{rllllllllllllllllllllll}
\hline 220 & 210 & 200 & 190 & 180 & 170 & 160 & 150 & 140 & 130 & 120 & 110 & 100 & 90 & 80 & 70 & 60 & 50 & 40 & 10 & 10 & 10
\end{tabular}

Figure S9. ${ }^{13} \mathrm{C}$ NMR spectrum of 2 in in $\mathrm{DMSO}^{-\mathrm{d}_{6}}$ 


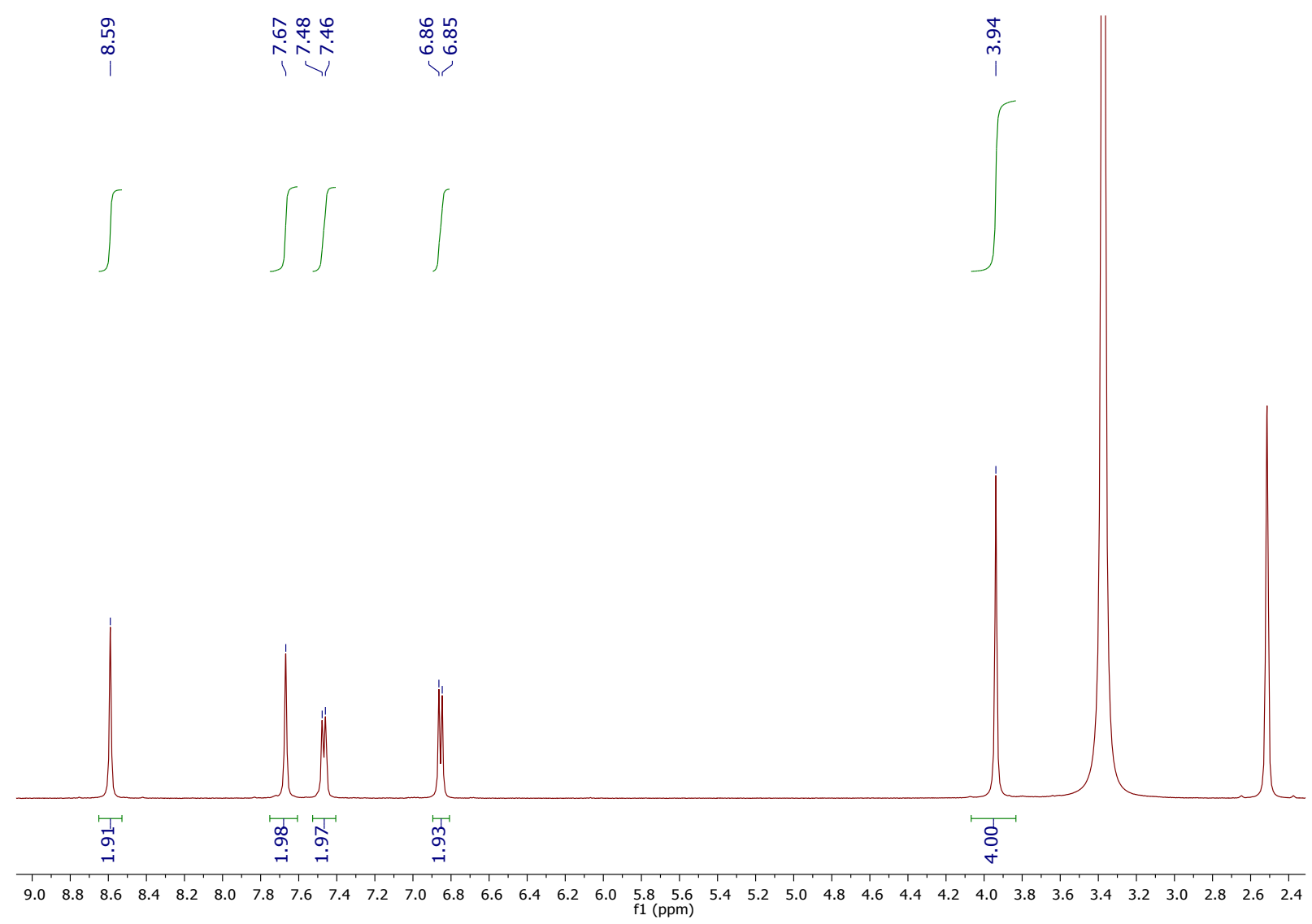

Figure S10. ${ }^{1} \mathrm{H}$ NMR spectrum of 3 in $\mathrm{DMSO}^{-\mathrm{d}_{6}}$

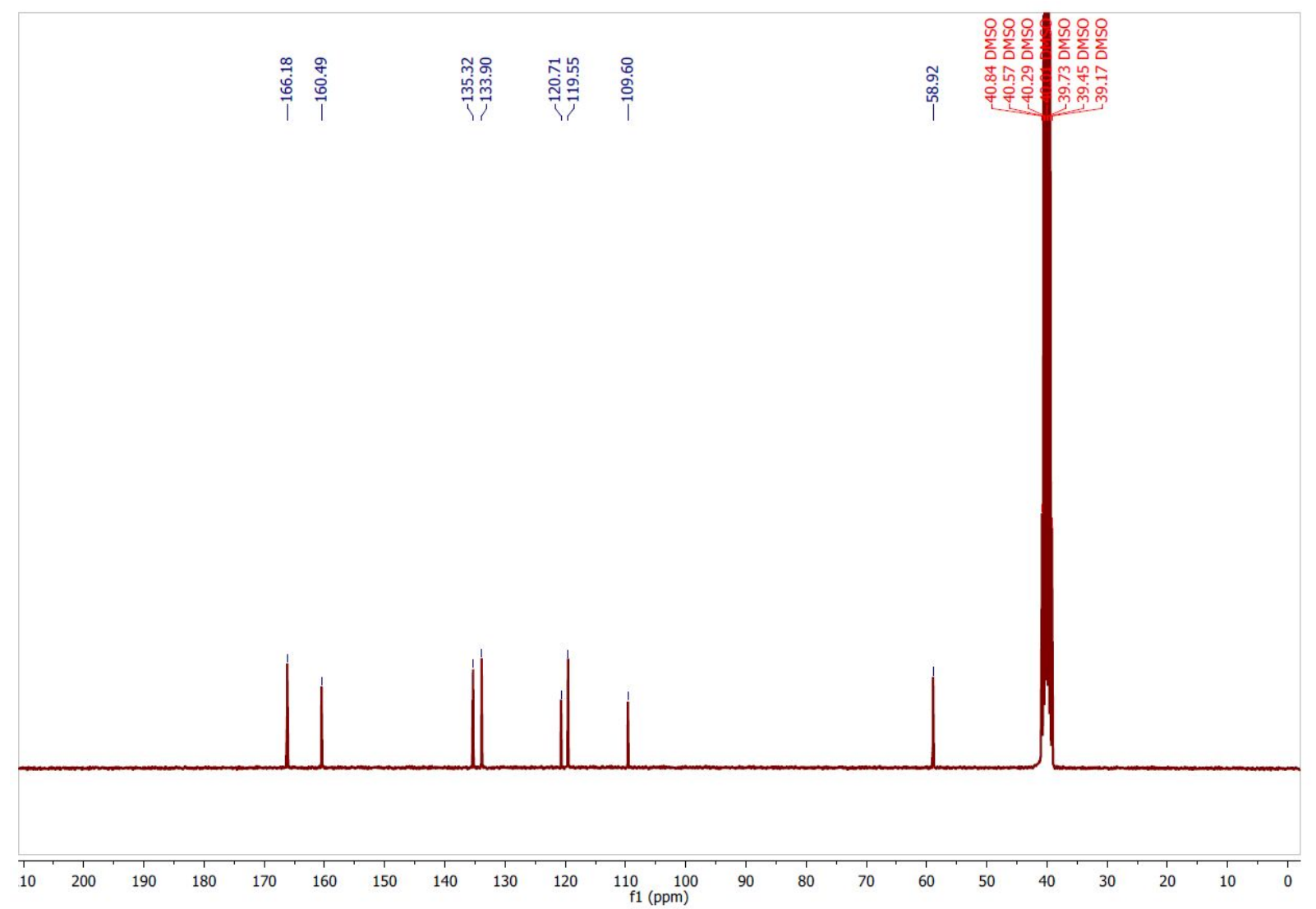

Figure S11. ${ }^{13} \mathrm{C}$ NMR spectrum of 3 in DMSO- $\mathrm{d}_{6}$ 

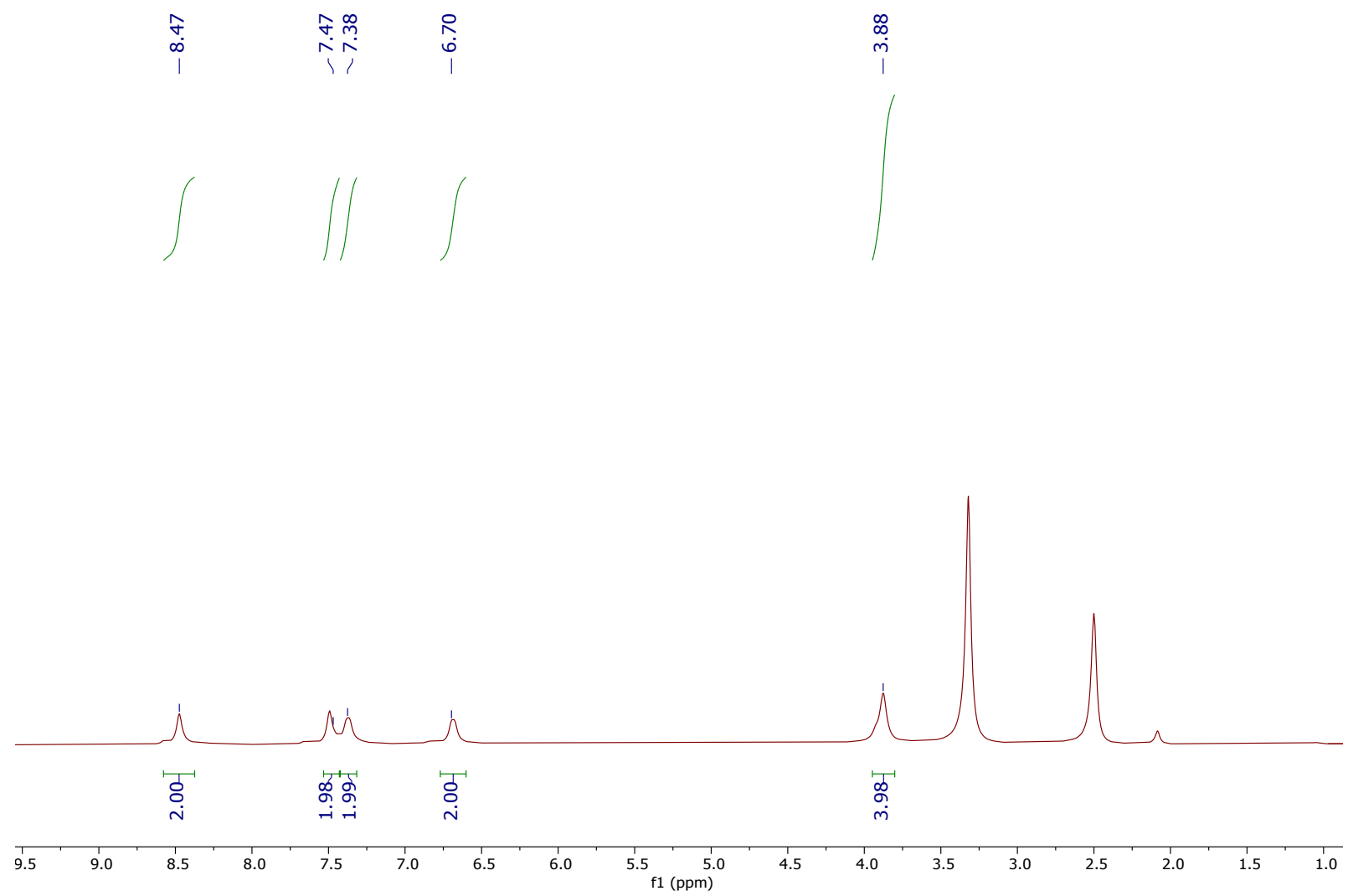

Figure S12. ${ }^{1} \mathrm{H}$ NMR spectrum of 4 in $\mathrm{DMSO}^{-\mathrm{d}_{6}}$

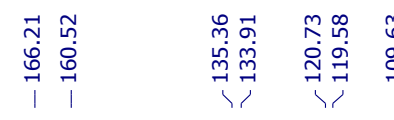

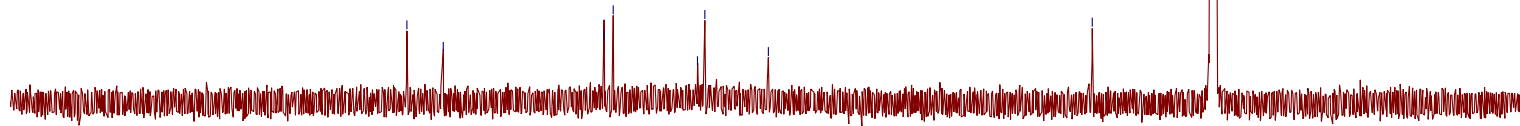

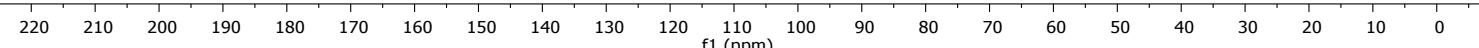

Figure S13. ${ }^{13} \mathrm{C}$ NMR spectrum of 4 in DMSO- $\mathrm{d}_{6}$ 
Elemental Composition Report

Tolerance $=10.0 \mathrm{PPM} / \mathrm{DBE}: \min =-1.5, \max =50.0$

Element prediction: Off

Number of isotope peaks used for $\mathrm{i}-\mathrm{FIT}=3$

Monoisotopic Mass, Even Electron Ions

13 formula(e) evaluated with 1 results within limits (up to 50 closest results for each mass)

Elements Used:

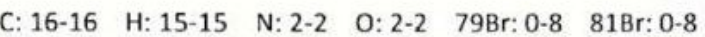

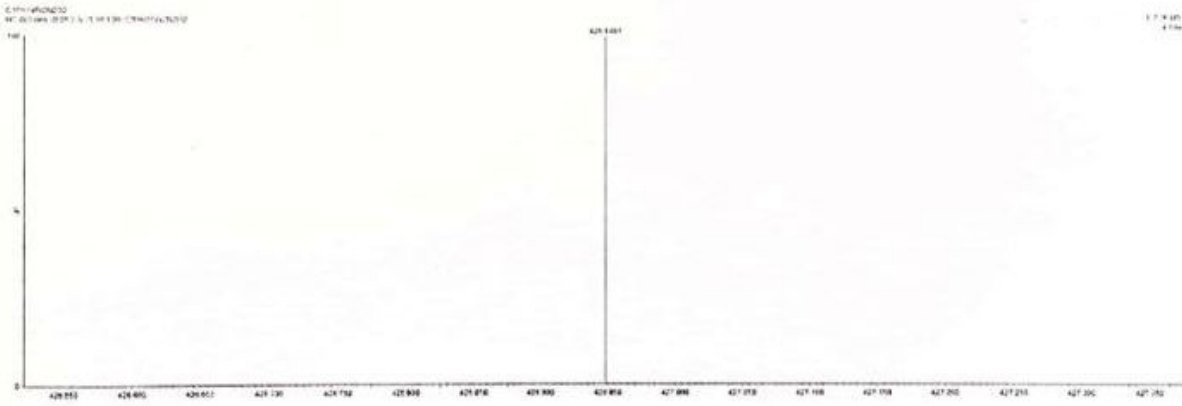

Minimum

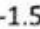

Maximum:

$\begin{array}{lll}5.0 & 10.0 \quad 50.0\end{array}$

Mass

Calc. Mass

mDa PPM DBE i-FIT Norm Conf(\%)

Formula

426.9481

426.9480

$0.1 \quad 0.2$

9.5

$79 \mathrm{Br} 81 \mathrm{Br}$

Figure S14. TOF-MS-ES+ for $[\mathrm{M}+\mathrm{H}]^{+} \mathrm{Br}$-Salen. 
Elemental Composition Report

Tolerance $=10.0 \mathrm{PPM} / \mathrm{DBE}: \min =-1.5, \max =50.0$

Element prediction: Off

Number of isotope peaks used for $\mathrm{i}-\mathrm{FIT}=3$

Monoisotopic Mass, Even Electron lons

40 formula(e) evaluated with 1 results within limits (up to 50 closest results for each mass)

Elements Used:

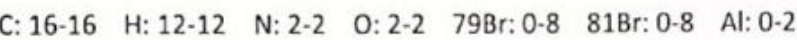

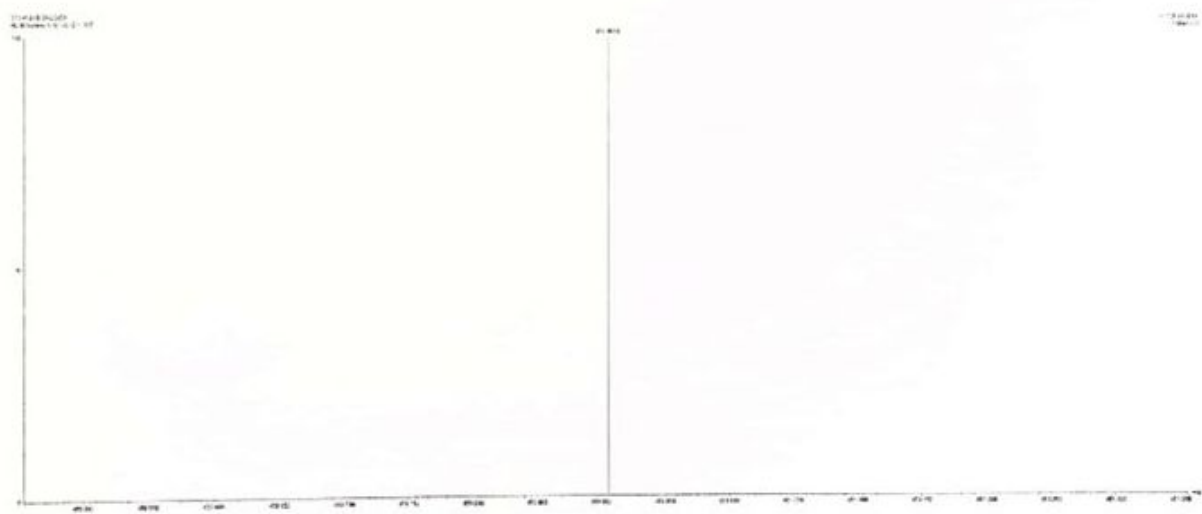

Minimum:

$-1.5$

Maximum:

$5.0 \quad 10.0 \quad 50.0$

Mass

Calc. Mass

MP PPM DBE

450.9058

450.9060

$-0$.

$79 \mathrm{Br} 81 \mathrm{Br} \mathrm{Al}$

Figure S15. TOF-MS-ES+ for $[\mathrm{M}+\mathrm{H}]^{+} \mathrm{Br}-\mathrm{Salen} \mathrm{Al}$. 
Elemental Composition Report

Tolerance $=10.0$ PPM / DBE $: \min =-1.5, \max =50.0$

Element prediction: Off

Number of isotope peaks used for $\mathrm{i}-\mathrm{FIT}=3$

Monoisotopic Mass, Even Electron Ions

33 formula(e) evaluated with 1 results within limits (up to 50 closest results for each mass)

Elements Used:

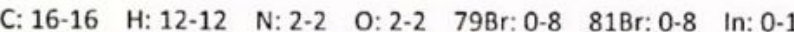

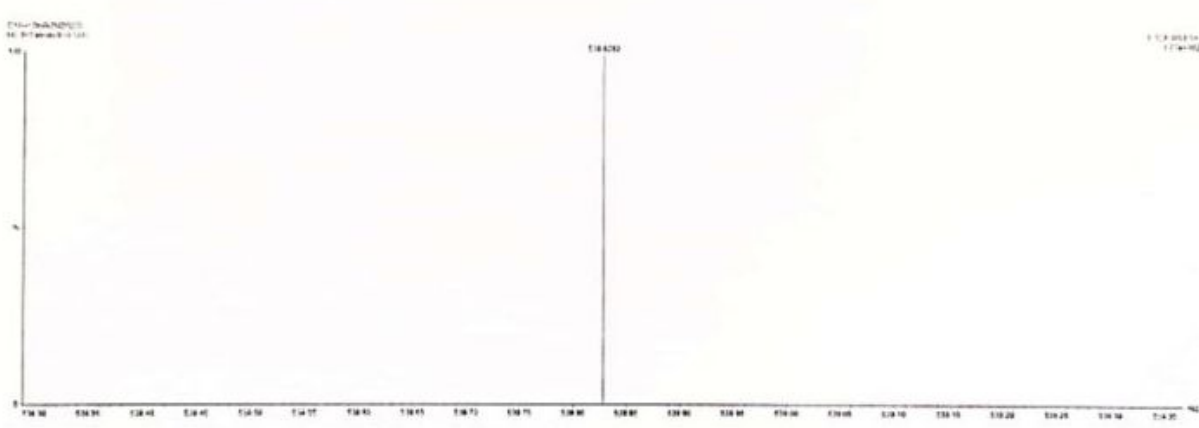

\begin{tabular}{|c|c|c|c|c|c|c|c|c|}
\hline Minimum: & & & -1.5 & & & & & \\
\hline Maximum: & 5.0 & 10.0 & 50.0 & & & & & \\
\hline Mass & Calc. Mass & $\mathrm{mDa}$ & PPM & DBE & $\mathrm{i}-\mathrm{FIT}$ & Norm & Conf $(\%)$ & Formula \\
\hline 538.8282 & 538.8284 & -0.2 & -0.4 & 11.5 & 8.2 & $n / a$ & $n / a$ & $\mathrm{C} 16 \mathrm{H}_{12} \mathrm{~N}_{2} \mathrm{O} 2$ \\
\hline
\end{tabular}

Figure S16. TOF-MS-ES+ for $[\mathrm{M}+\mathrm{H}]^{+} \mathrm{Br}-\mathrm{Salen} \operatorname{In}$. 
Elemental Composition Report

Tolerance $=10.0$ PPM / DBE: $\min =-1.5, \max =50.0$

Element prediction: Off

Number of isotope peaks used for $\mathrm{i}-\mathrm{FIT}=3$

Monoisotopic Mass, Even Electron Ions

19 formula(e) evaluated with 1 results within limits (up to 50 closest results for each mass)

Elements Used:

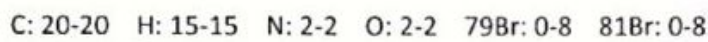

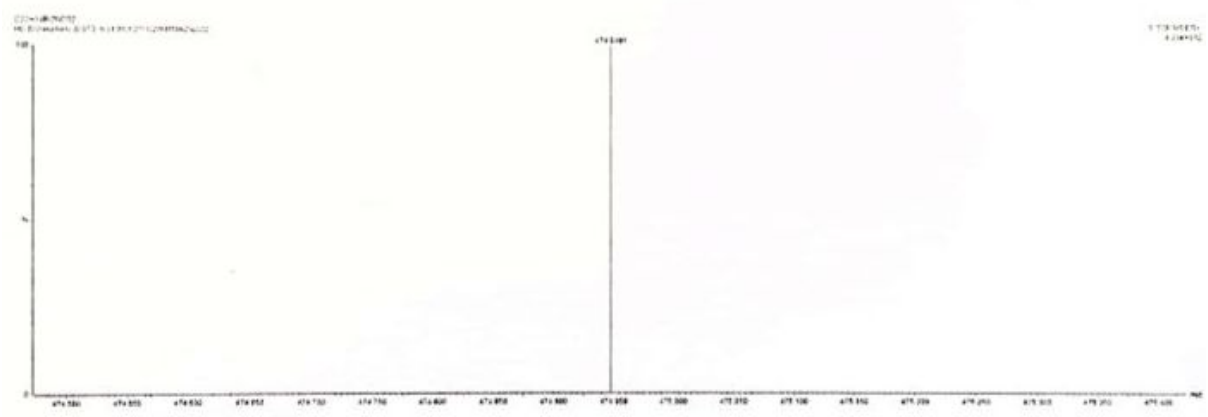

Minimum: $-1.5$

Maximum: 5.0

$10.0 \quad 50.0$

Mass Calc. Mass mDa PPM DBE i-FIT Norm Conf(\%) Formula

$\begin{array}{lllllllll}474.9481 & 474.9480 & 0.1 & 0.2 & 13.5 & 74.7 & \text { n/a } & \text { n/a } & \text { C2O H15 N2 O2 }\end{array}$

$79 \mathrm{Br} 81 \mathrm{Br}$

Figure S17. TOF-MS-ES+ for $[\mathrm{M}+\mathrm{H}]^{+} \mathrm{Br}-\mathrm{Salophen}$. 
Elemental Composition Report

Tolerance $=10.0 \mathrm{PPM} / \mathrm{DBE}: \min =-1.5, \max =50.0$

Element prediction: Off

Number of isotope peaks used for $\mathrm{i}-\mathrm{FIT}=3$

Monoisotopic Mass, Even Electron Ions

52 formula(e) evaluated with 1 results within limits (up to 50 closest results for each mass)

Elements Used:

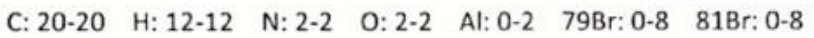

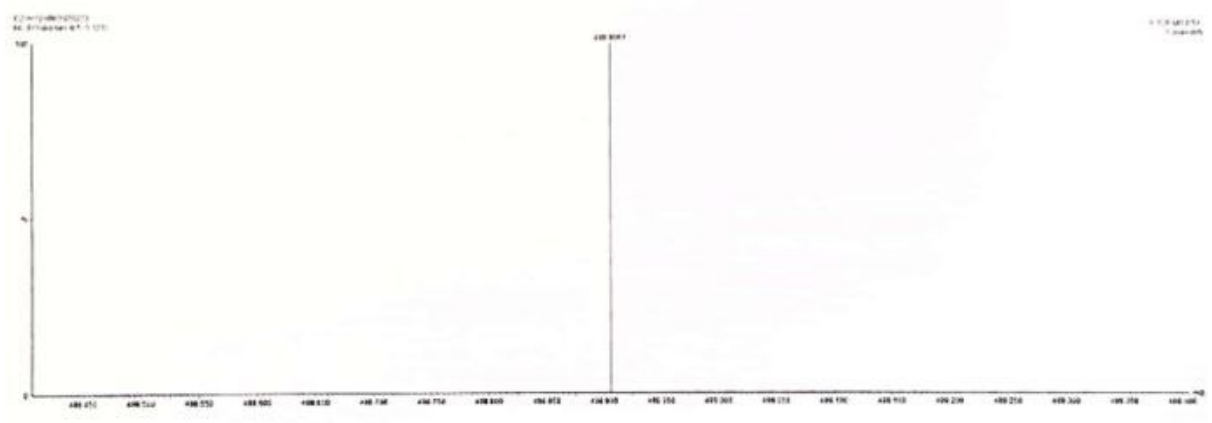

\begin{tabular}{|c|c|c|c|c|c|c|c|c|}
\hline Minimum: & & & -1.5 & & & & & \\
\hline Maximum: & 5.0 & 10.0 & 50.0 & & & & & \\
\hline Mass & Calc. Mass & $\mathrm{mDa}$ & PPM & DBE & $\mathrm{i}-\mathrm{FIT}$ & Norm & Conf(\%) & Formula \\
\hline 498.9061 & 498.9060 & 0.1 & 0.2 & 15.5 & 35.7 & $\mathrm{n} / \mathrm{a}$ & $\mathrm{n} / \mathrm{a}$ & $\mathrm{C} 20 \mathrm{H} 12 \mathrm{~N} 2 \mathrm{O} 2 \mathrm{Al}$ \\
\hline $79 \mathrm{Br} 81 \mathrm{Br}$ & & & & & & & & \\
\hline
\end{tabular}

Figure S18. TOF-MS-ES+ for $[\mathrm{M}+\mathrm{H}]^{+} \mathrm{Br}-\mathrm{Salophen}-\mathrm{Al}$. 
Elemental Composition Report

Tolerance $=10.0 \mathrm{PPM} / \mathrm{DBE}: \min =-1.5, \max =50.0$

Element prediction: Off

Number of isotope peaks used for $\mathrm{i}-\mathrm{FIT}=3$

Monoisotopic Mass, Even Electron Ions

43 formula(e) evaluated with 1 results within limits (up to 50 closest results for each mass)

Elements Used:

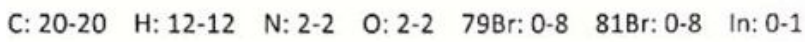

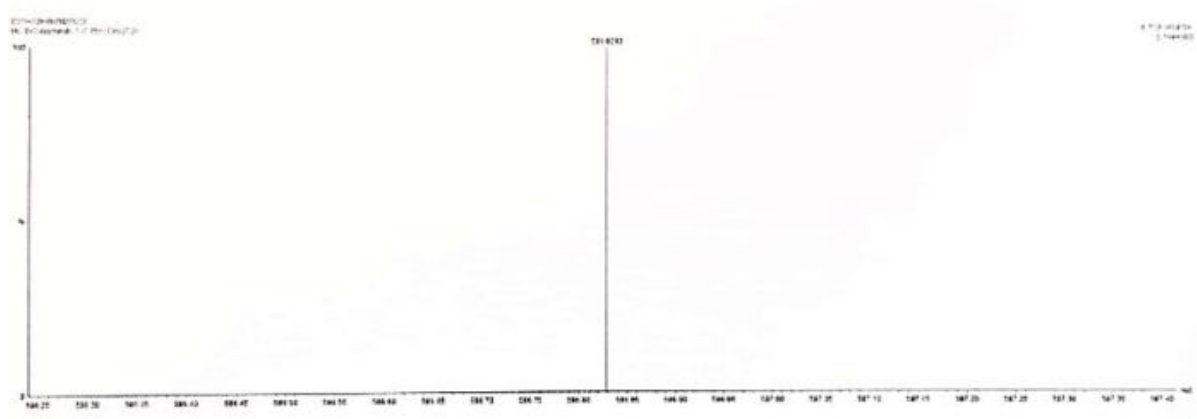

Minimum:

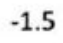

Maximum: $\quad 5.0 \quad 10.0 \quad 50.0$

Mass Calc. Mass mDa PPM DBE I-FIT Norm Conf(\%) Formula

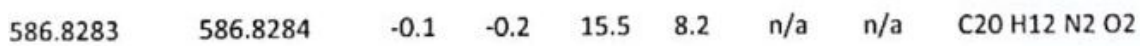

$79 \mathrm{Br} 81 \mathrm{Br}$ In

Figure S19. TOF-MS-ES+ for $[\mathrm{M}+\mathrm{H}]^{+} \mathrm{Br}-\mathrm{Salophen}$ In. 


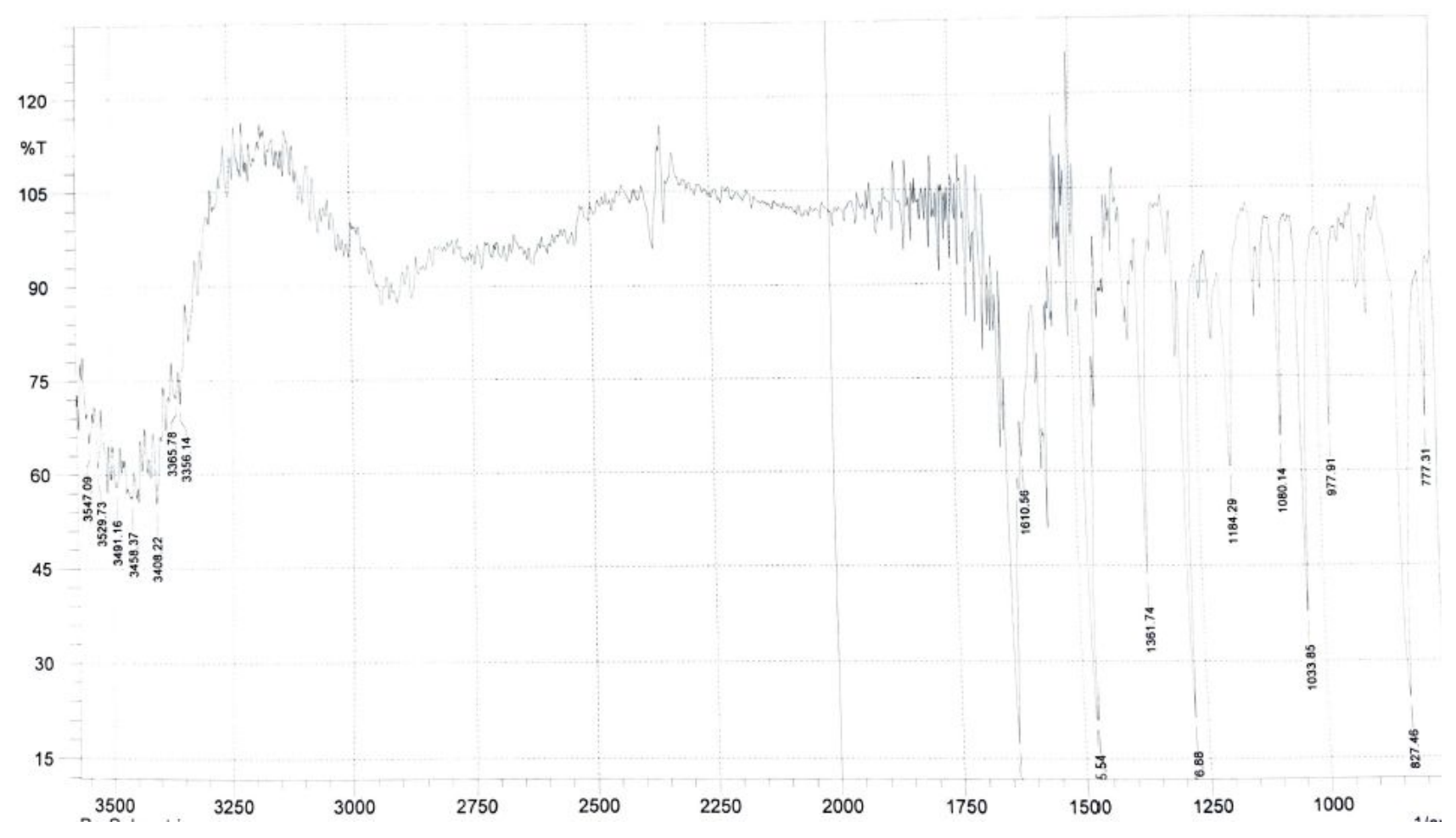

Figure S20. IR spectra of Br-Salen

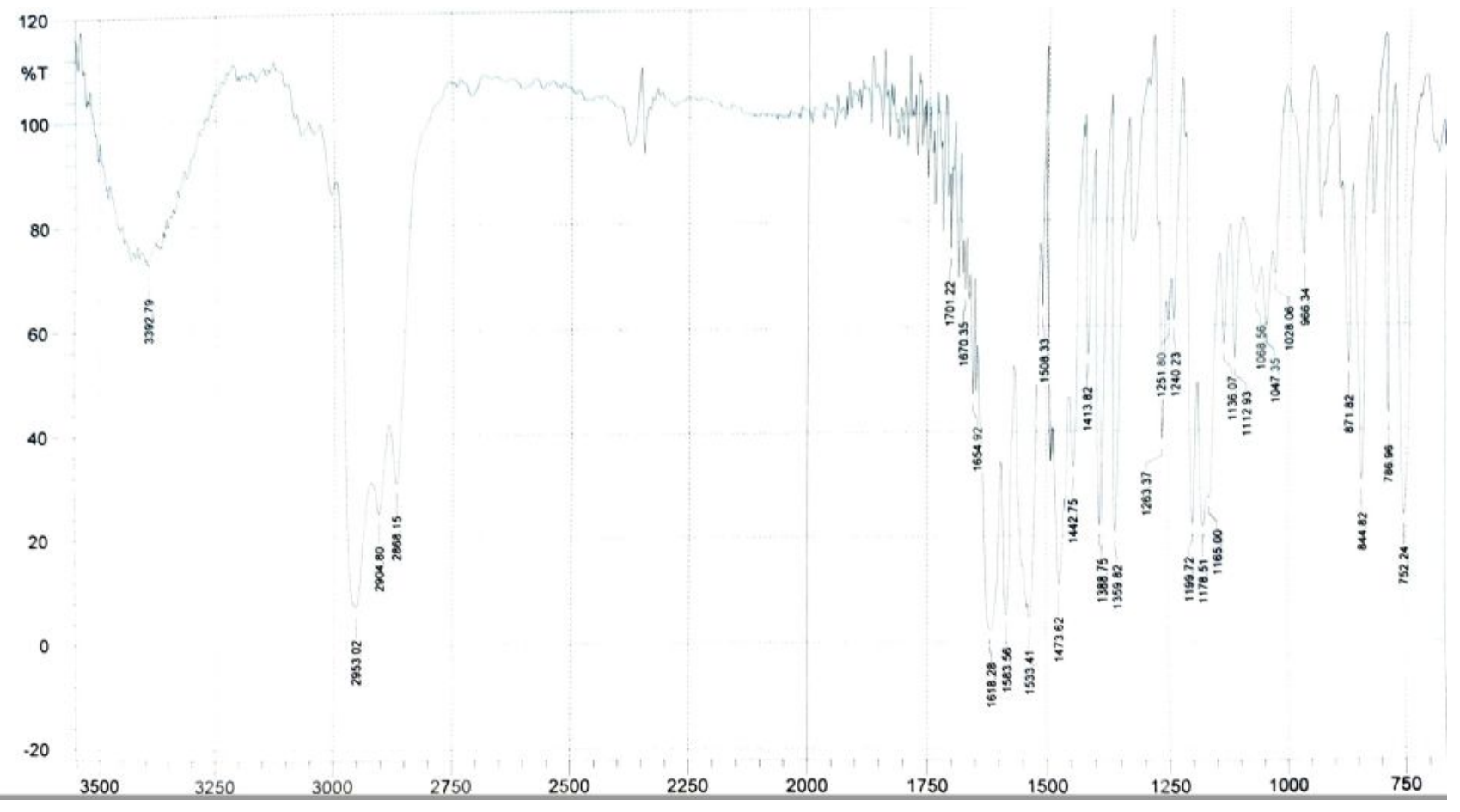

Figure S21. IR spectra of $\mathrm{Br}$-Salophen 


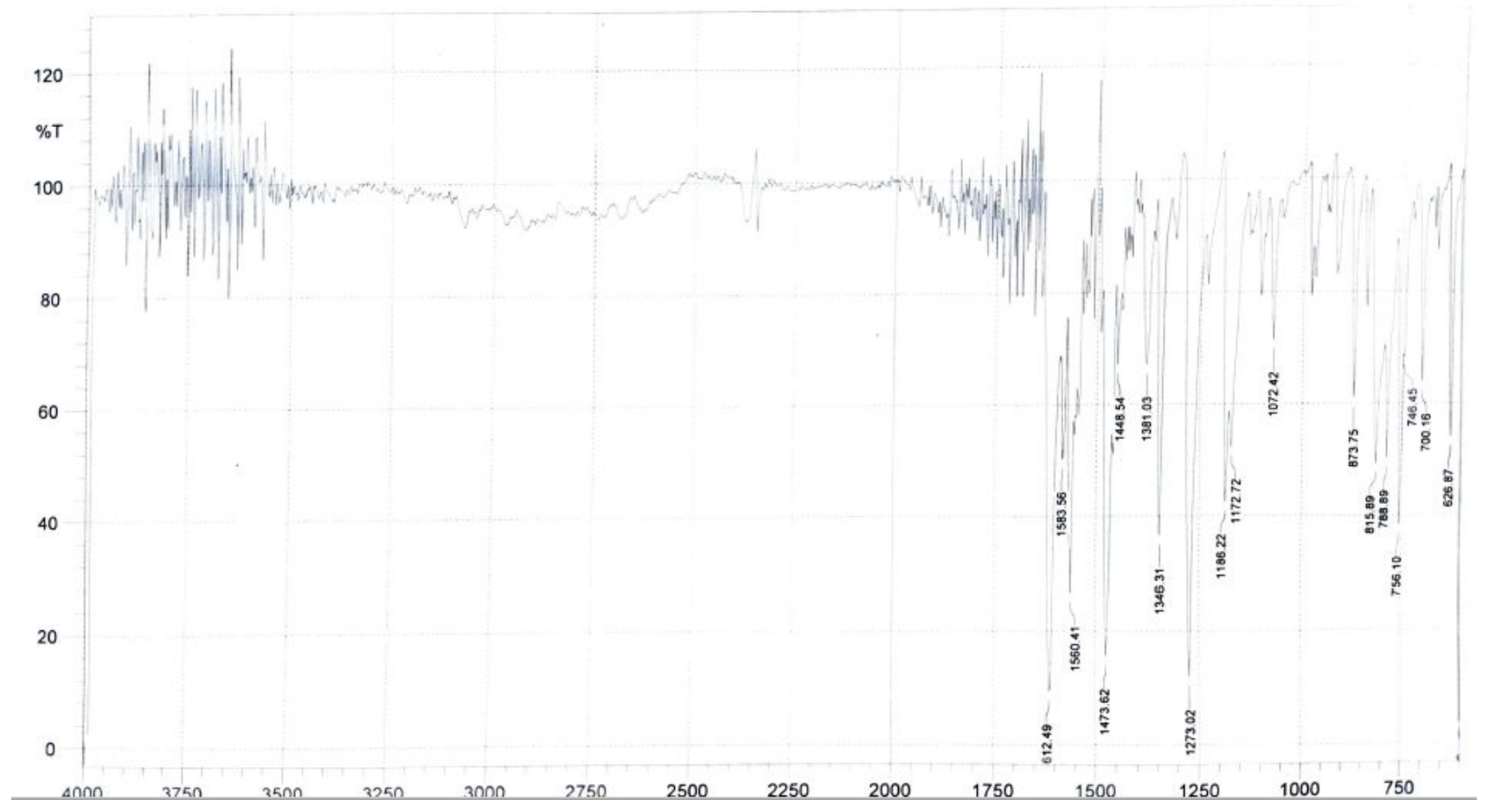

Figure S22. IR spectra of 1

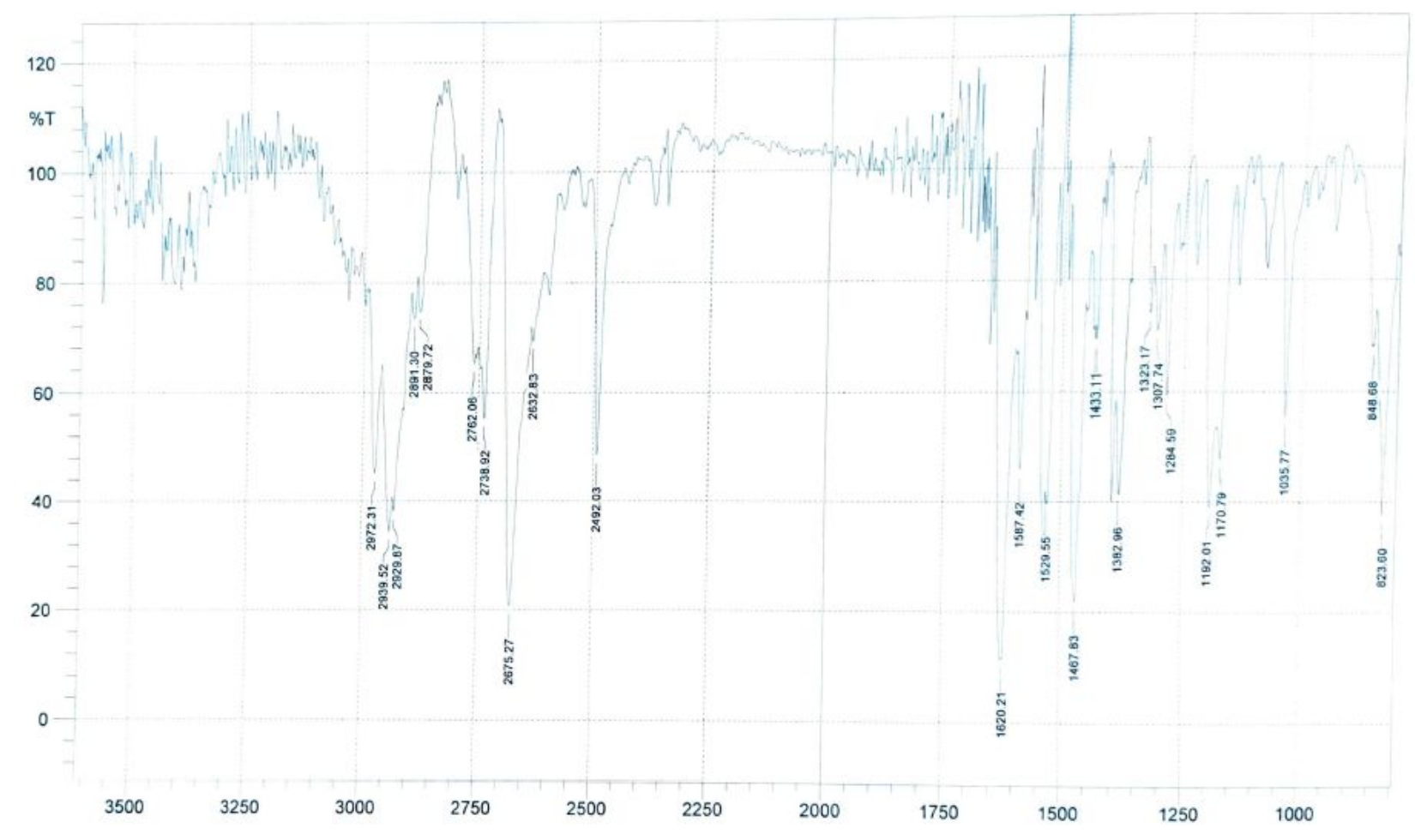

Figure S23. IR spectra of $\mathbf{2}$ 


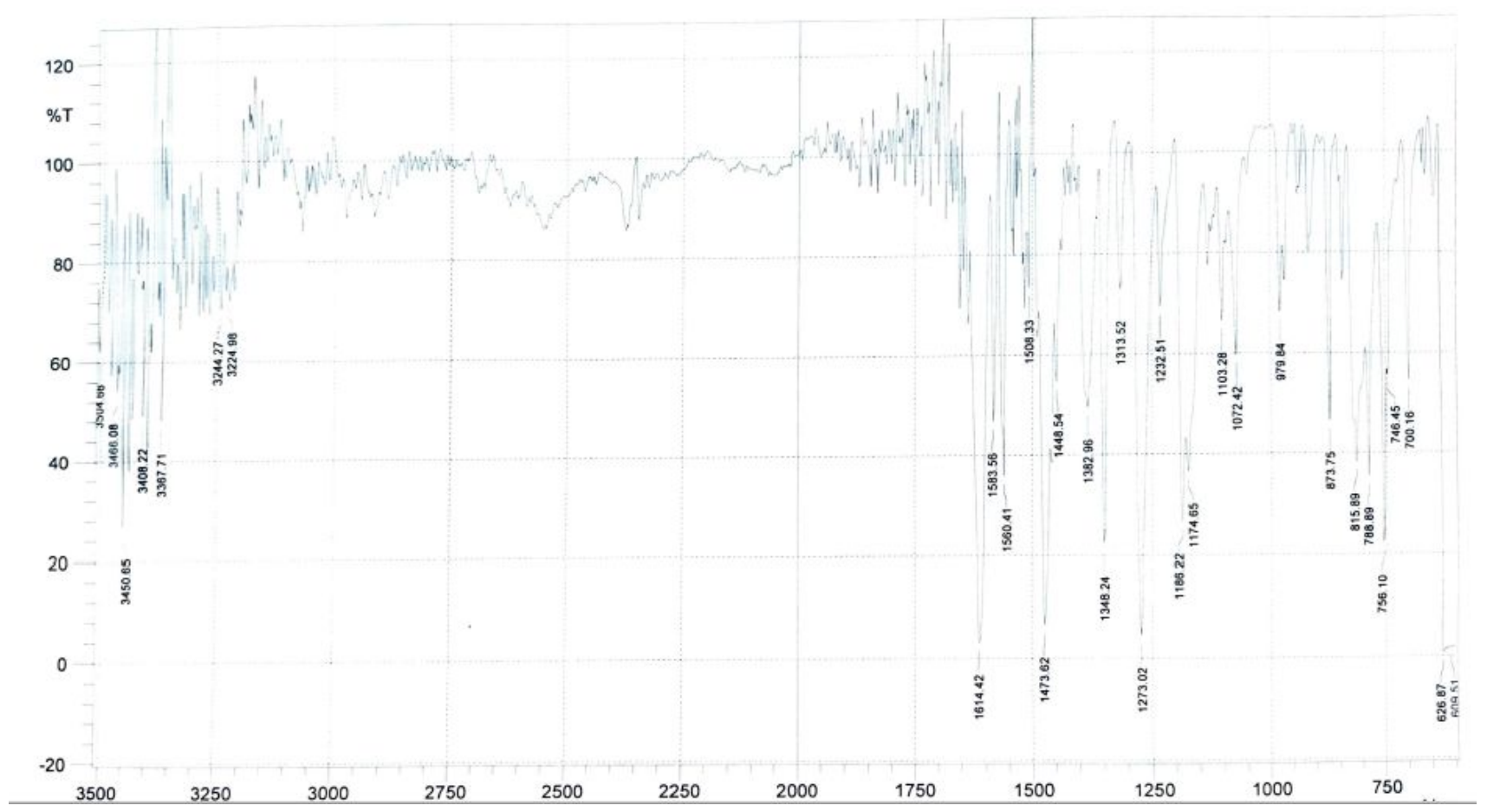

Figure S24. IR spectra of 3

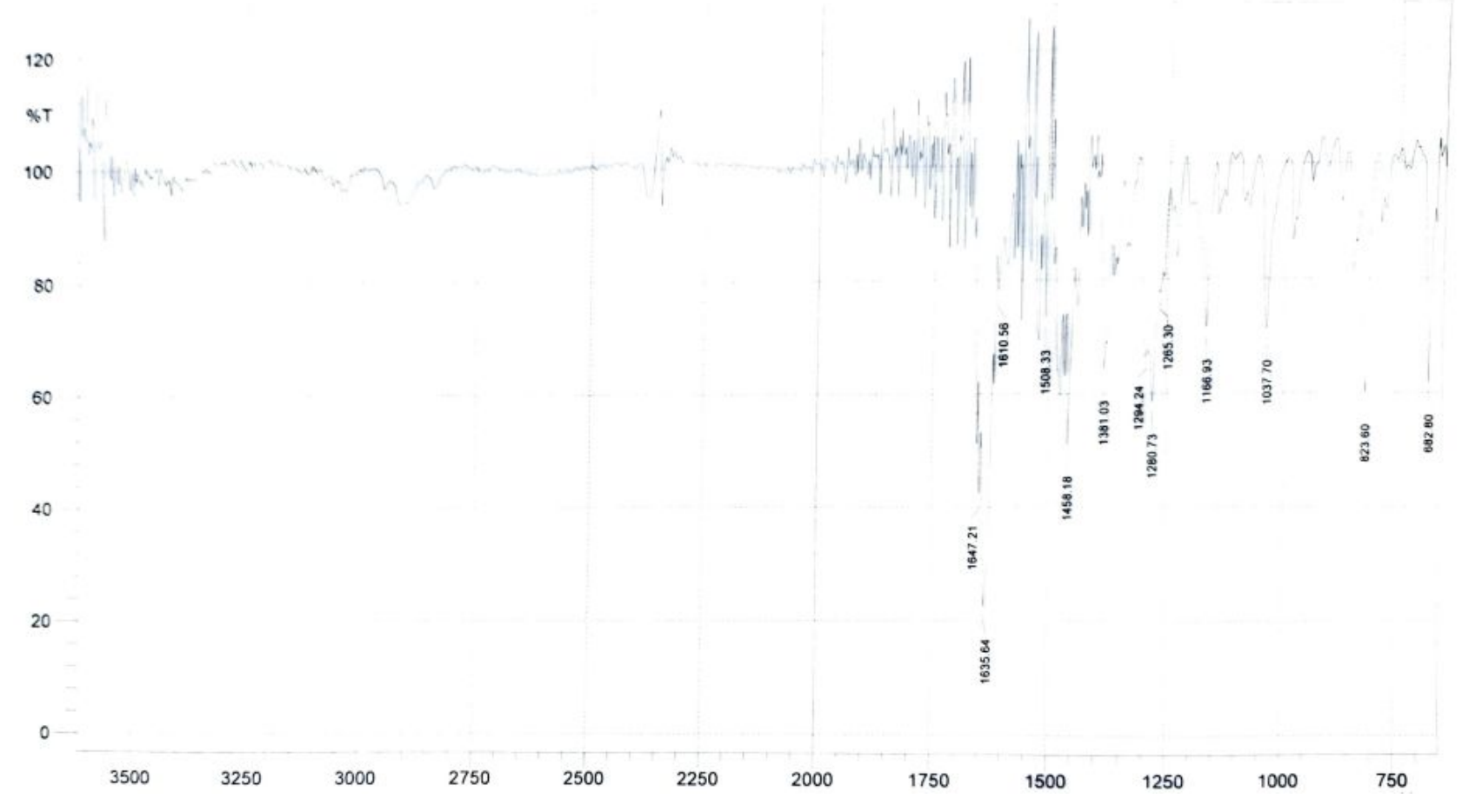

Figure S25. IR spectra of 4 
D. Green chemistry metrics (GCM) calculations for "Br-Salophen-Al (Cl)" 1 at different scales D-1. E-factor calculations

Mechanosynthesis of "Br-Salophen-Al (Cl)" (without base)

\section{General formula used*:}

$$
\mathrm{E}=\frac{\text { Benzaldehyde }+ \text { diamine }+\mathrm{AlCl} 3-\text { total product }}{\text { total product }}
$$

* All quantities are expressed in grams

$0.1 \mathrm{~g}$

$$
\begin{gathered}
E=\frac{0.081+0.02+0.029-0.087}{0.087} \\
E=0.49
\end{gathered}
$$

$1 \mathrm{~g}$;

$$
\begin{gathered}
E=\frac{0.805+0.2+0.275-0.98}{0.98} \\
E=0.306
\end{gathered}
$$

$30 \mathrm{~g}$;

$$
\begin{gathered}
E=\frac{24+6.5+7.6-22.3}{22.3} \\
E=0.70
\end{gathered}
$$

$60 \mathrm{~g}$;

$$
\begin{gathered}
E=\frac{49.5+13.3+17.5-53.8}{53.8} \\
E=0.49
\end{gathered}
$$


$120 \mathrm{~g}$;

$$
\begin{gathered}
E=\frac{96.68+26+26.43-90.09}{90.09} \\
E=0.65
\end{gathered}
$$

Mechanosynthesis of "Br-Salophen-Al (Cl)" (with base)

\section{General formula used:}

$$
\mathrm{E}=\frac{\text { benzaldehyde }+ \text { diamine }+\mathrm{AlCl} 3+\mathrm{Et} 3 \mathrm{~N}+\mathrm{H} 2 \mathrm{O}(10 \%)-\text { total product }}{\text { total product }}
$$

* All quantities are expressed in grams

$30 \mathrm{~g}$;

$$
\begin{gathered}
E=\frac{24+6.5+7.6+11.7+40-22.3}{22.3} \\
E=2.98
\end{gathered}
$$

$60 \mathrm{~g}$

$$
\begin{gathered}
E=\frac{49.5+13.3+17.5+25.4+80-53.8}{53.8} \\
E=2.45
\end{gathered}
$$

$120 \mathrm{~g}$;

$$
\begin{gathered}
E=\frac{96.68+26+26.43+41+160-90.09}{90.09} \\
E=2.88
\end{gathered}
$$

Conventional solution synthesis of "Br-Salophen-Al (Cl)" (without base)

\section{General formula used:}




$$
\mathrm{E}=\frac{\text { benzaldehyde }+ \text { diamine }+\mathrm{EtOH}(10 \%)+\mathrm{AlCl} 3+\text { Toluene }(10 \%)-\text { total product }}{\text { total product }}
$$

* All quantities are expressed in grams

$0.1 \mathrm{~g}$

$$
\begin{aligned}
E= & \frac{(0.081+0.02+0.1578)+0.0275+0.0876-0.063}{0.063} \\
& E=4.93
\end{aligned}
$$

$1 \mathrm{~g}$;

$$
\begin{aligned}
& E= \frac{(1.022+0.275+1.1835)+0.275+0.7008-0.96}{0.96} \\
& E=2.60
\end{aligned}
$$

$30 \mathrm{~g}$;

$$
\begin{gathered}
E=\frac{(30+8.12+39.45)+7.6+21.9-20.7}{20.7} \\
E=4.17
\end{gathered}
$$

$60 \mathrm{~g}$;

$$
\begin{gathered}
E=\frac{(50+13.5+63.12)+17.6+43.8-57.5}{57.5} \\
E=2.27
\end{gathered}
$$

$120 \mathrm{~g}$

$$
\begin{gathered}
E=\frac{(96.68+26+126.24)+30.45+78.84-94}{94} \\
E=2.81
\end{gathered}
$$




\section{General formula used:}

E

benzaldehyde + diamine + EtOH $(10 \%)+\operatorname{AlCl} 3+$ toluene $(10 \%)+$ Et3N + H2O (10\%) - total product total product

* All quantities are expressed in grams

$30 \mathrm{~g}$;

$$
\begin{gathered}
E=\frac{(30+8.12+39.45)+7.6+21.9+11.7+40-20.7}{20.7} \\
E=6.67
\end{gathered}
$$

$60 \mathrm{~g}$;

$$
E=\frac{(50+13.5+63.12)+17.6+43.8+24.7+80-57.5}{57.5}
$$

$$
\mathrm{E}=4.09
$$

$120 \mathrm{~g}$;

$$
\begin{gathered}
E=\frac{(96.68+26+126.24)+30.45+78.84+42+160-94}{94} \\
E=4.96
\end{gathered}
$$

D-2. Process mass intensity (PMI) calculations

Mechanosynthesis of "Br-Salophen-Al (Cl)" (without base)

\section{General Formula used}

$$
M I=\frac{(\text { benzaldehyde }+ \text { diamine })+(\text { Ligand used }+ \text { AlCl3 })-\text { Ligand total }}{\text { Complex total }}
$$

* All quantities are expressed in grams

$0.1 \mathrm{~g}$; 


$$
\begin{aligned}
& P M I=\frac{(0.081+0.02)+(0.088+0.029)-0.088}{0.087} \\
& P M I=1.49
\end{aligned}
$$

$1 \mathrm{~g}$;

$$
\begin{aligned}
& \mathrm{PMI}=\frac{(0.805+0.2)+(0.88+0.275)-0.88}{0.98} \\
& \mathrm{PMI}=1.3
\end{aligned}
$$

$30 \mathrm{~g}$;

$$
\mathrm{PMI}=\frac{(24+6.5)+(23.5+7.6)-23.5}{22.3}
$$

$$
\mathrm{PMI}=1.7
$$

$60 \mathrm{~g}$;

$$
\begin{aligned}
& \mathrm{PMI}=\frac{(49.5+13.3)+(53.8+17.5)-53.8}{53.8} \\
& \mathrm{PMI}=1.49
\end{aligned}
$$

$120 \mathrm{~g}$;

$$
\begin{gathered}
\mathrm{PMI}=\frac{(96.68+26)+(94+26.43)-94}{90.09} \\
\mathrm{PMI}=1.65
\end{gathered}
$$

Mechanosynthesis of "Br-Salophen-Al (Cl)" (with base)

\section{General Formula used}

$$
\text { MI }=\frac{(\text { benzaldehyde }+ \text { diamine })+(\text { Ligand used }+ \text { AlCl3 }+ \text { Et3N }+ \text { H2O })-\text { Ligand total }}{\text { Complex total }}
$$

* All quantities are expressed in grams

$30 \mathrm{~g}$; 


$$
\mathrm{PMI}=\frac{(24+6.5)+(23.5+7.6+11.7+400)-23.5}{22.3}
$$

$$
\mathrm{PMI}=20.17
$$

$60 \mathrm{~g} ;$

$$
\begin{aligned}
& \mathrm{PMI}=\frac{(49.5+13.3)+(53.8+17.5+25.4+800)-53.8}{53.8} \\
& \mathrm{PMI}=16.83
\end{aligned}
$$

$120 \mathrm{~g}$;

$$
\begin{aligned}
& \mathrm{PMI}=\frac{(96.68+26)+(94+26.43+41+1600)-94}{90.09} \\
& \mathrm{PMI}=19.87
\end{aligned}
$$

Conventional solution synthesis of "Br-Salophen-Al (Cl)" (without base)

\section{General Formula used}

$$
\text { MI }=\frac{(\text { benzaldehyde }+ \text { diamine }+ \text { EtOH })+(\text { Ligand used }+ \text { AlCl3 }+ \text { Toluene })-\text { Ligand total }}{\text { Complex total }}
$$

$0.1 \mathrm{~g}$

$$
\begin{aligned}
& \mathrm{PMI}=\frac{(0.081+0.02+1.578)+(0.088+0.0275+0.876)-0.077}{0.063} \\
& \mathrm{PMI}=41.16
\end{aligned}
$$

$1 \mathrm{~g}$;

$$
\mathrm{PMI}=\frac{(1.022+0.275+11.835)+(0.88+0.275+6.936)-1.077}{0.96}
$$

$$
\text { PMI }=20.98
$$

$30 \mathrm{~g}$; 


$$
\mathrm{PMI}=\frac{(30+8.12+394.5)+(23.5+7.6+216.75)-30.1}{20.7}
$$

$$
\mathrm{PMI}=31.41
$$

$60 \mathrm{~g}$;

$$
\begin{gathered}
\mathrm{PMI}=\frac{(50+13.5+631.2)+(54.5+17.6+433.5)-54.5}{57.5} \\
\mathrm{PMI}=19.92
\end{gathered}
$$

$120 \mathrm{~g}$;

$$
\begin{aligned}
& \mathrm{PMI}=\frac{(96.68+26+1262.4)+(94.39+30.45+780.3)-94.39}{94} \\
& \mathrm{PMI}=23.35
\end{aligned}
$$

Conventional solution synthesis of "Br-Salophen-Al (Cl)" (with base)

$30 \mathrm{~g}$;

$$
\begin{aligned}
& \mathrm{PMI}=\frac{(30+8.12+394.5)+(23.5+7.6+216.75+11.7+400)-30.1}{20.7} \\
& \quad \mathrm{PMI}=51.30
\end{aligned}
$$

$60 \mathrm{~g}$

$$
\mathrm{PMI}=\frac{(50+13.5+631.2)+(54.5+17.6+433.5+24.7+800)-54.5}{57.5}
$$

$$
\mathrm{PMI}=34.27
$$

$120 \mathrm{~g}$;

$$
\begin{aligned}
& \mathrm{PMI}=\frac{(96.68+26+1262.4)+(94.39+30.45+780.3+1600)-94.39}{94} \\
& \mathrm{PMI}=40.38
\end{aligned}
$$

D-3. Generalized Reaction mass efficiency (RME) 


\section{Mechanosynthesis of "Br-Salophen- $\mathrm{Al}(\mathrm{Cl})$ "}

$0.1 \mathrm{~g}$

$$
\begin{aligned}
& \mathrm{RME}=\frac{0.087}{0.081+0.02+0.029} \\
& \mathrm{RME}=0.67
\end{aligned}
$$

$1 \mathrm{~g}$;

$$
\begin{gathered}
\mathrm{RME}=\frac{0.98}{0.805+0.2+0.275} \\
\mathrm{RME}=0.76
\end{gathered}
$$

$30 \mathrm{~g}$;

$$
\begin{gathered}
\mathrm{RME}=\frac{22.3}{24+6.5+7.6} \\
\mathrm{RME}=0.58
\end{gathered}
$$

$60 \mathrm{~g}$;

$$
\begin{gathered}
\mathrm{RME}=\frac{53.8}{49.5+13.3+17.5} \\
\mathrm{RME}=0.67
\end{gathered}
$$

$120 \mathrm{~g}$;

$$
\begin{gathered}
\mathrm{RME}=\frac{90.09}{96.68+26+26.43} \\
\mathrm{RME}=0.60
\end{gathered}
$$


$0.1 \mathrm{~g}$

$$
\begin{gathered}
\mathrm{RME}=\frac{0.063}{0.081+0.02+0.0275} \\
\mathrm{RME}=0.49
\end{gathered}
$$

$1 \mathrm{~g}$;

$$
\begin{gathered}
\mathrm{RME}=\frac{0.96}{1.022+0.275+0.275} \\
\mathrm{RME}=0.61
\end{gathered}
$$

$30 \mathrm{~g}$;

$$
\begin{gathered}
\mathrm{RME}=\frac{20.7}{30+8.12+7.6} \\
\mathrm{RME}=0.45
\end{gathered}
$$

$60 \mathrm{~g}$;

$$
\begin{gathered}
\mathrm{RME}=\frac{57.5}{50+13.5+17.6} \\
\mathrm{RME}=0.70
\end{gathered}
$$

$120 \mathrm{~g}$;

$$
\begin{gathered}
\mathrm{RME}=\frac{94}{96.68+26+30.45} \\
\mathrm{RME}=0.61
\end{gathered}
$$

D-4. Energy Usage Calculation

Energy consumption at each step of the mechanosynthesis process was calculated based on the following equation $(1 \mathrm{~kW}=3.6 \mathrm{MJ})$ :

Energy consumption by unit operation/process $(\mathrm{kWh})=$ Power rating of the instrument $(\mathrm{kW}) \mathrm{X}$ Time of operation (h) 
$\%$ Energy saved $=\frac{\text { Energy used (Solution method }- \text { Mechanosynthesis) }}{\text { Energy used in Solution method }} \times 100$

Power consumption of:

Planetary mill $($ Grinder, BM4 $)=1,600 \mathrm{~W}(4$ station $)$

Planetary mill $($ Retsch, PM 100) $=1,250 \mathrm{~W}(1$ station $)$

Vibratory shaker mill $($ Retsch, MM400 $)=150 \mathrm{~W}(2$ station $)$

Hot plate stirrer (Hei-standard), $=800 \mathrm{~W}$

\section{Mechanosynthesis of "Br-Salophen-Al (Cl)"}

$0.1 \mathrm{~g}$

Energy used for $0.1 \mathrm{~g}$ scale reaction;

$=(0.15 \mathrm{~kW} \times 2 \mathrm{~h})+(0.15 \mathrm{~W} \times 4 \mathrm{~h})$

$=0.3 \mathrm{kWh}+0.6 \mathrm{kWh}$

$=0.9 \mathrm{kWh} / 0.0001 \mathrm{Kg}$

$=9000 \mathrm{kWhKg}^{-1}\left(32,400 \mathrm{MJKg}^{-1}\right)$

$1 \mathrm{~g}$

Energy used for $1 \mathrm{~g}$ scale reaction;

$=(0.15 \mathrm{~kW} \times 2 \mathrm{~h})+(0.15 \mathrm{~W} \times 4 \mathrm{~h})$

$=0.3 \mathrm{kWh}+0.6 \mathrm{kWh}$

$=0.9 \mathrm{kWh} / 0.001 \mathrm{Kg}$

$=900 \mathrm{kWhKg}^{-1}\left(3,240 \mathrm{MJKg}^{-1}\right)$

$30 \mathrm{~g}$;

Energy used for $30 \mathrm{~g}$ scale reaction;

$=(1.25 \mathrm{~kW} \times 2 \mathrm{~h})+(1.25 \mathrm{~W} \times 4 \mathrm{~h})$

$=2.5 \mathrm{kWh}+5 \mathrm{kWh}$ 
$=7.5 \mathrm{kWh} / 0.030 \mathrm{Kg}$

$=250 \mathrm{kWhKg}^{-1}\left(900 \mathrm{MJKg}^{-1}\right)$

$60 \mathrm{~g}$;

Energy used for $60 \mathrm{~g}$ scale reaction;

$=(1.25 \mathrm{~kW} \times 2 \mathrm{~h})+(1.25 \mathrm{~W} \times 4 \mathrm{~h})$

$=2.5 \mathrm{kWh}+5 \mathrm{kWh}$

$=7.5 \mathrm{kWh} / 0.060 \mathrm{Kg}$

$=125 \mathrm{kWhKg}^{-1}\left(450 \mathrm{MJKg}^{-1}\right)$

$120 \mathrm{~g}$;

Energy used for $120 \mathrm{~g}$ scale reaction;

$=(1.6 \mathrm{~kW} \times 2 \mathrm{~h})+(1.6 \mathrm{~kW} \times 4 \mathrm{~h})$

$=9.6 \mathrm{kWh} / 0.120 \mathrm{Kg}$

$=80 \mathrm{kWhKg}^{-1}\left(288 \mathrm{MJKg}^{-1}\right)$

\section{Solution-synthesis of "Br-Salophen- $\mathrm{Al}(\mathrm{Cl})$ "}

$0.1 \mathrm{~g}$

Energy used for $0.1 \mathrm{~g}$ scale reaction;

$=(0.8 \mathrm{~kW}$ x $4 \mathrm{~h})+(0.8 \mathrm{~kW} \times 12 \mathrm{~h})$

$=12.8 \mathrm{kWh} / 0.0001 \mathrm{~g}$

$=128,000 \mathrm{kWhKg}^{-1}\left(460,800 \mathrm{MJKg}^{-1}\right)$

$1 \mathrm{~g}$;

Energy used for $1 \mathrm{~g}$ scale reaction;

$=(0.8 \mathrm{~kW} \times 4 \mathrm{~h})+(0.8 \mathrm{~kW} \times 12 \mathrm{~h})$

$=12.8 \mathrm{kWh} / \mathrm{g}$ 
$=12,800 \mathrm{kWhKg}^{-1}\left(46,080 \mathrm{MJKg}^{-1}\right)$

$30 \mathrm{~g}$;

Energy used for $30 \mathrm{~g}$ scale reaction;

$=(0.8 \mathrm{~kW} \times 4 \mathrm{~h})+(0.8 \mathrm{~kW} \times 12 \mathrm{~h})$

$=12.8 \mathrm{kWh} / 0.030 \mathrm{Kg}$

$=426.67 \mathrm{kWhKg}^{-1}\left(1,536 \mathrm{MJKg}^{-1}\right)$

$60 \mathrm{~g} ;$

Energy used for $60 \mathrm{~g}$ scale reaction;

$=(0.8 \mathrm{~kW}$ x $4 \mathrm{~h})+(0.8 \mathrm{~kW} \times 12 \mathrm{~h})$

$=12.8 \mathrm{kWh} / 0.060 \mathrm{Kg}$

$=213.34 \mathrm{kWhKg}^{-1}\left(768 \mathrm{MJKg}^{-1}\right)$

$120 \mathrm{~g}$;

Energy used for $120 \mathrm{~g}$ scale reaction;

$=(0.8 \mathrm{~kW} \times 4 \mathrm{~h})+(0.8 \mathrm{~kW} \times 12 \mathrm{~h})$

$=12.8 \mathrm{kWh} / 0.120 \mathrm{Kg}$

$=106.67 \mathrm{kWhKg}^{-1}\left(384 \mathrm{MJKg}^{-1}\right)$ 


\section{D-5. Cost Calculation}

Table S1. Average Price of Electricity to Ultimate Customers by End-Use Sector, by State, May 2020 and 2019 (Cents per Kilowatthour) reproduced from https://www.eia.gov/electricity/monthly/epm table grapher.php?t=epmt 56 a) accessed in May 2020. Data used for calculation in Table $\mathbf{S 1}$ are highlighted in yellow.

\begin{tabular}{|c|c|c|c|c|c|c|c|c|c|c|}
\hline \multirow[b]{2}{*}{$\begin{array}{l}\text { Census Division } \\
\text { and State }\end{array}$} & \multicolumn{2}{|c|}{ Residential } & \multicolumn{2}{|c|}{ Commercial } & \multicolumn{2}{|l|}{ Industrial } & \multicolumn{2}{|c|}{ Transportation } & \multicolumn{2}{|c|}{ All Sectors } \\
\hline & $\begin{array}{r}\text { May } \\
2020\end{array}$ & May 2019 & May 2020 & May 2019 & May 2020 & $\begin{array}{r}\text { May } \\
2019\end{array}$ & $\begin{array}{r}\text { May } \\
2020\end{array}$ & May 2019 & $\begin{array}{r}\text { May } \\
2020\end{array}$ & May 2019 \\
\hline New England & 21.63 & 21.63 & 15.49 & 16.08 & 12.86 & 12.49 & 6.85 & 8.06 & 17.69 & 17.53 \\
\hline Connecticut & 23.96 & 23.35 & 16.87 & 17.21 & 14.32 & 13.20 & 11.04 & 11.81 & 19.84 & 19.16 \\
\hline Maine & 16.82 & 18.14 & 12.64 & 12.64 & 9.02 & 9.23 & -- & -- & 13.67 & 13.75 \\
\hline Massachusetts & 22.27 & 22.31 & 15.20 & 16.11 & 13.87 & 13.92 & 4.73 & 4.97 & 17.77 & 17.89 \\
\hline New Hampshire & 19.34 & 20.72 & 15.21 & 15.76 & 12.91 & 12.80 & -- & -- & 16.69 & 17.06 \\
\hline Rhode Island & 21.20 & 20.95 & 15.42 & 16.66 & 15.96 & 15.82 & 42.45 & 18.81 & 17.83 & 18.25 \\
\hline Vermont & 19.75 & 17.39 & 16.82 & 16.13 & 10.97 & 10.64 & -- & -- & 16.43 & 15.10 \\
\hline Middle Atlantic & 16.07 & 16.01 & 12.30 & 11.97 & 6.34 & 6.66 & 10.67 & 11.21 & 12.47 & 12.12 \\
\hline New Jersey & 15.63 & 16.80 & 12.69 & 12.92 & 9.73 & 10.53 & 9.55 & 8.55 & 13.56 & 13.94 \\
\hline New York & 18.53 & 17.34 & 13.88 & 13.37 & 5.33 & 5.78 & 10.98 & 12.36 & 14.55 & 13.83 \\
\hline Pennsylvania & 13.99 & 14.24 & 8.84 & 8.77 & 6.15 & 6.31 & 8.80 & 7.48 & 9.86 & 9.55 \\
\hline East North Central & 13.94 & 14.07 & 10.27 & 10.28 & 6.73 & 6.79 & 6.19 & 7.39 & 10.42 & 10.07 \\
\hline Illinois & 14.10 & 14.14 & 9.22 & 9.16 & 6.39 & 6.21 & 5.90 & 7.21 & 9.98 & 9.55 \\
\hline Indiana & 12.65 & 13.06 & 10.69 & 10.86 & 6.88 & 7.29 & 10.94 & 11.15 & 9.70 & 9.80 \\
\hline Michigan & 16.32 & 15.74 & 11.73 & 11.40 & 8.06 & 7.05 & 11.42 & 10.60 & 12.60 & 11.27 \\
\hline Ohio & 12.32 & 12.93 & 9.52 & 9.83 & 5.83 & 6.35 & 6.82 & 7.46 & 9.42 & 9.49 \\
\hline Wisconsin & 15.24 & 15.34 & 11.10 & 11.07 & 7.44 & 7.47 & 15.21 & 14.21 & 11.24 & 10.94 \\
\hline West North Central & 12.90 & 12.91 & 10.12 & 10.01 & 7.16 & 7.17 & 8.57 & 8.24 & 10.11 & 9.95 \\
\hline lowa & 14.35 & 14.02 & 11.18 & 10.46 & 6.39 & 6.05 & -- & -- & 9.44 & 9.07 \\
\hline
\end{tabular}




\begin{tabular}{|c|c|c|c|c|c|c|c|c|c|c|}
\hline Kansas & 13.75 & 13.58 & 10.78 & 10.65 & 7.07 & 7.15 & -- & -- & 10.65 & 10.42 \\
\hline Minnesota & 13.71 & 13.86 & 10.66 & 10.85 & 8.03 & 7.98 & 10.73 & 9.43 & 10.97 & 10.77 \\
\hline Missouri & 12.12 & 12.20 & 9.49 & 9.51 & 6.61 & 6.90 & 7.22 & 7.03 & 10.17 & 10.11 \\
\hline Nebraska & 11.70 & 11.69 & 9.36 & 8.96 & 7.50 & 7.17 & - & - & 9.39 & 9.02 \\
\hline North Dakota & 11.27 & 11.41 & 9.45 & 9.06 & 7.90 & 8.45 & - & -- & 9.07 & 9.22 \\
\hline South Dakota & 12.13 & 12.17 & 9.24 & 9.47 & 7.70 & 7.77 & -- & -- & 9.99 & 10.02 \\
\hline South Atlantic & 11.29 & 12.00 & 8.68 & 9.31 & 5.75 & 6.29 & 8.41 & 8.16 & 9.34 & 9.89 \\
\hline Delaware & 13.58 & 14.00 & 10.13 & 9.80 & 6.85 & 7.43 & -- & -- & 10.98 & 10.92 \\
\hline District of Columbia & 12.77 & 13.87 & 12.28 & 12.47 & 8.17 & 8.25 & 10.31 & 10.47 & 12.26 & 12.59 \\
\hline Florida & 9.83 & 11.73 & 7.53 & 9.40 & 5.48 & 7.64 & 5.52 & 7.79 & 8.67 & 10.48 \\
\hline Georgia & 11.81 & 11.75 & 9.94 & 9.72 & 5.14 & 5.81 & 5.00 & 5.12 & 9.63 & 9.60 \\
\hline Maryland & 13.23 & 13.49 & 9.98 & 10.30 & 7.71 & 7.70 & 8.28 & 7.63 & 11.30 & 11.35 \\
\hline North Carolina & 11.72 & 11.54 & 8.53 & 8.46 & 5.74 & 5.86 & 8.33 & 8.11 & 9.22 & 9.15 \\
\hline South Carolina & 12.75 & 12.38 & 10.34 & 9.90 & 5.65 & 5.83 & - & - & 9.63 & 9.42 \\
\hline Virginia & 12.36 & 12.46 & 7.73 & 8.29 & 6.30 & 7.15 & 9.86 & 8.35 & 9.20 & 9.56 \\
\hline West Virginia & 12.03 & 11.98 & 9.51 & 9.10 & 6.19 & 5.96 & -- & -- & 8.80 & 8.30 \\
\hline East South Central & 11.62 & 11.75 & 10.88 & 10.64 & 5.43 & 5.81 & -- & -- & 9.34 & 9.38 \\
\hline Alabama & 12.66 & 12.90 & 11.51 & 11.66 & 5.80 & 6.33 & -- & -- & 9.75 & 10.01 \\
\hline Kentucky & 11.13 & 11.18 & 10.66 & 10.16 & 5.17 & 5.43 & -- & -- & 8.67 & 8.54 \\
\hline Mississippi & 11.80 & 11.94 & 10.77 & 10.57 & 5.41 & 5.92 & -- & - & 9.19 & 9.33 \\
\hline Tennessee & 10.99 & 10.99 & 10.60 & 10.25 & 5.19 & 5.38 & - & - & 9.55 & 9.43 \\
\hline West South Central & 11.36 & 11.60 & 7.79 & 7.90 & 4.77 & 5.31 & 6.84 & 6.69 & 8.12 & 8.23 \\
\hline Arkansas & 10.48 & 10.19 & 8.70 & 8.68 & 5.46 & 5.81 & 11.77 & 13.38 & 8.06 & 7.98 \\
\hline Louisiana & 9.66 & 10.25 & 8.64 & 9.08 & 4.85 & 5.67 & 8.28 & 9.51 & 7.44 & 8.09 \\
\hline Oklahoma & 9.88 & 10.42 & 7.21 & 7.53 & 4.19 & 4.82 & -- & - & 7.13 & 7.46 \\
\hline
\end{tabular}




\begin{tabular}{|c|c|c|c|c|c|c|c|c|c|c|}
\hline Texas & 11.98 & 12.19 & 7.66 & 7.70 & 4.75 & 5.22 & 6.77 & 6.46 & 8.42 & 8.41 \\
\hline Mountain & 12.05 & 12.20 & 9.76 & 9.64 & 6.11 & 6.09 & 9.03 & 8.99 & 9.55 & 9.29 \\
\hline Arizona & 12.99 & 13.25 & 10.94 & 10.87 & 6.31 & 6.38 & 10.24 & 9.99 & 11.20 & 10.98 \\
\hline Colorado & 12.06 & 12.02 & 10.15 & 10.05 & 7.20 & 7.13 & 8.00 & 8.13 & 9.94 & 9.76 \\
\hline Idaho & 9.90 & 10.37 & 7.69 & 7.81 & 6.18 & 6.09 & -- & -- & 7.67 & 7.82 \\
\hline Montana & 11.67 & 11.66 & 10.85 & 10.62 & 4.41 & 4.22 & -- & -- & 8.99 & 8.73 \\
\hline Nevada & 11.42 & 12.34 & 7.28 & 7.45 & 4.74 & 5.27 & 9.39 & 7.88 & 8.14 & 8.10 \\
\hline New Mexico & 12.24 & 12.21 & 9.89 & 9.53 & 5.35 & 5.45 & -- & -- & 8.91 & 8.63 \\
\hline Utah & 10.56 & 10.50 & 8.99 & 8.88 & 5.99 & 5.69 & 10.70 & 10.59 & 8.50 & 8.27 \\
\hline Wyoming & 11.52 & 11.57 & 10.16 & 9.92 & 7.14 & 6.77 & -- & -- & 8.53 & 8.13 \\
\hline Pacific Contiguous & 15.86 & 15.82 & 14.50 & 13.73 & 10.07 & 9.42 & 9.43 & 8.12 & 14.02 & 13.41 \\
\hline California & 18.69 & 18.89 & 16.69 & 15.65 & 13.65 & 12.76 & 9.36 & 7.88 & 16.85 & 16.10 \\
\hline Oregon & 11.41 & 11.25 & 9.39 & 8.98 & 6.06 & 5.94 & 9.61 & 9.21 & 9.24 & 8.95 \\
\hline Washington & 9.87 & 9.81 & 9.06 & 8.74 & 4.68 & 4.44 & 9.86 & 9.32 & 8.14 & 7.82 \\
\hline $\begin{array}{l}\text { Pacific } \\
\text { Noncontiguous }\end{array}$ & 27.85 & 29.07 & 25.11 & 25.67 & 22.06 & 23.99 & -- & -- & 25.08 & 26.11 \\
\hline Alaska & 23.17 & 22.65 & 20.37 & 20.12 & 15.81 & 16.56 & -- & -- & 20.32 & 20.12 \\
\hline Hawaii & 30.94 & 33.43 & 29.57 & 30.32 & 24.47 & 26.56 & -- & -- & 28.13 & 29.71 \\
\hline U.S. Total & 13.14 & 13.34 & 10.44 & 10.51 & 6.48 & 6.70 & 9.29 & 9.49 & 10.45 & 10.42 \\
\hline
\end{tabular}

See Technical notes for additional information on the Commercial, Industrial, and Transportation sectors.

Notes: - See Glossary for definitions. - Values are preliminary estimates based on a cutoff model sample.

See Technical Notes for a discussion of the sample design for the Form EIA-826.

Utilities and energy service providers may classify commercial and industrial customers based on either NAICS codes or demands or usage falling within specified limits by rate schedule.

Changes from year to year in consumer counts, sales and revenues, particularly involving the commercial and industrial consumer sectors, may result from respondent

implementation of changes in the definitions of consumers, and reclassifications.

Totals may not equal sum of components because of independent rounding.

Source: U.S. Energy Information Administration, Form EIA-861M (formerly EIA-826), Monthly Electric Power Industry Report. 